\title{
METODOLOGIA JURÍDICA EUROPEIA E MERCOSULISTA: CONSIDERAÇÕES FUNDAMENTAIS
}

\author{
METODOLOGÍA JURÍDICA EUROPEA Y \\ MERCOSULINA: CONSIDERACIONES \\ FUNDAMENTALES
}

Augusto Jaeger Junior

Resumo: O presente artigo discute a existência de uma metodologia jurídica no Mercosul, um bloco econômico intergovernamental, tendo por base a elogiável experiência supranacional, desenvolvida na União Europeia. Explorado é o fato de acreditar-se ser adequado o Mercosul restringir-se, no presente momento e estágio da integração, ao seu modelo original. Para tanto, em um primeiro momento, observa-se qual é o direito que o Mercosul tem, depois, quais são as características do direito da União Europeia, bem como a existência de uma verdadeira metodologia jurídica europeia, tudo isso com o propósito de ser, ao seu final, proposta a construção de uma metodologia jurídica mercosulista. É necessário admitir que ainda muito dela não existe, mas isso não quer dizer que a europeia possa ou deva ser transferida para o Mercosul.

Resumen: El presente artículo discute la existencia de una metodología jurídica para el Mercosur, -bloque económico intergubernamental-, teniendo por base la elogiable experiencia supranacional desarrollada en la Unión Europea. Observaremos que se considera adecuado para el Mercosur, en el presente momento y fase de la integración, limitarse a su modelo original. Para ello, en un primer momento, se observa cual es el Derecho que el Mercosur tiene; luego, cuales son las características del Derecho de la Unión Europea, así como la existencia de una verdadera metodología jurídica europea, todo eso con el propósito de ser, al final, una

\footnotetext{
* Artigo escrito com base em uma palestra proferida no Encontro Anual da Deutsch-Lusitanische Juristenvereinigung - DLJV, em Colônia, Alemanha, ocorrido entre os dias 25 e 26 de novembro de 2011. O autor agradece ao Dr. Jan Peter Schmidt, referente para a América Latina no MaxPlanck-Institut für ausländisches und internationales Privatrecht, de Hamburgo, ao Dr. Carl Friedrich Nordmeier, assistente científico no Instituto de Direito Privado Internacional e Estrangeiro, da Universidade de Colônia, e ao Dr. Marcelo De Nardi, Juiz Federal em Porto Alegre, pelas discussões acadêmicas que muito contribuíram para a elaboração desse artigo. ** O autor, Augusto Jaeger Junior, é professor de direito internacional público e privado na Faculdade de Direito da Universidade Federal do Rio Grande do Sul, em Porto Alegre. Tem doutorado em Direito pela UFRGS e Mestrado em Direito pela UFSC, Brasil. Bolsista de Produtividade em Pesquisa do CNPq, Brasil.
} 
propuesta para la construcción de una metodología jurídica mercosulina. Es necesario admitir que todavía mucho de ella no existe, pero que eso no quiere decir que la europea pueda o deba ser transferida para el Mercosur.

Palavras-chave: União Europeia, Mercosul, Sistema de solução de controvérsias, Supranacionalidade, Metodologia jurídica

Palabras clave: Unión Europea, Mercosur, Sistema de solución de controvérsias, Supranacionalidad, Metodología jurídica

\section{INTRODUÇÃO}

No Encontro Anual da Associação Luso-Alemã de Juristas ocorrido em Brasília, em novembro de 2009, promovi uma forte defesa do processo de integração desenvolvido no Mercosul e do seu modelo institucional. Instituições com poderes supranacionais seriam inadequadas ao Mercosul, ademais de enfrentarem obstáculos de ordem constitucional ${ }^{1}$. De fato, há uma parte da doutrina que tem por elogiável a experiência supranacional, mas que também acredita ser adequado o Mercosul restringir-se, no presente momento e estágio da integração, ao modelo intergovernamental. Mesmo o sistema atual de solução de controvérsias do Mercosul seria apropriado, pois condiz com o estágio de integração em que se encontram os Estados-partes.

A respeito de defendê-lo, observei que uma defesa mais veemente parece vir do exterior. Wehner fala da funcionalidade de um novo tipo de projeto de integração (Funktionsfähigkeit eines neuartigen Integrationsprojektes), ao escrever sobre o Mercosul. O processo tem suas particularidades, que o diferencia de todos os outros automaticamente comparáveis. A principal delas envolve diferenciações com o modelo comunitário, como a impossibilidade de comparação de seus órgãos, a ausência de um tribunal permanente nos moldes do Tribunal de Justiça da União Europeia e a opção pela intergovernabilidade ${ }^{2}$. Enfim, defendi que o método escolhido colhe consentimentos.

Com base em suas particularidades metodológicas, o Mercosul pode ser considerado um novo modelo de integraçã̃o, que tem a seu serviço um novo direito. $\mathrm{O}$ caminho que o processo optou por percorrer para o alcance de um mercado comum é diferente do caminho que a União Europeia tomou. Justamente o caráter intergovernamental, a

1 Que em relação ao Brasil podem ser conferidos em MARTINS Renata Rocha de Mello (2002) Verfassungskonformität des MERCOSUR in Brasilien. Baden-Baden: Nomos Verlagsgesellschaft, p. 137-185.

2 WEHNER Ulrich (1999) Der Mercosur: Rechtsfragen und Funktionsfähigkeit eines neuartigen Integrationsprojektes und die Erfolgsaussichten der interregionalen Kooperation mit der Europäischen Union. Baden-Baden: Nomos Verlagsgesellschaft, p. 46 e 58-59. 
dependência do processo dos quereres dos presidentes das democracias e o poder de veto dos Estados-partes, que são criticados pela maioria dos autores, são fatores vistos como vantajosos por outros. O processo já teria alcançado muito mais do que havia sido esperado no momento de sua fundação, em 1991.

Em 2009, eu também havia reportado como surpreendente a conclusão de Fuders, para quem o Mercosul já estaria muito próximo de um mercado comum, mesmo que não seja visto um paralelismo entre as liberdades econômicas fundamentais no processo de integração, pelo fato de que também a União Europeia, quando o anunciou, em 1992, não as tinha todas conformadas. Ao final, eu ainda disse que seguiria contaminado por esses pensamentos de otimismo e, do ponto de vista institucional, instigado pelas oportunidades que se apresentam na Europa para que expuséssemos a nossa realidade, como a de hoje.

Para esse encontro em Colônia, os organizadores me propuseram o tema da Metodologia Jurídica Europeia e Mercosulista: Considerações Fundamentais. Informo desde já que as considerações que farei serão bem fundamentais mesmo, uma vez que não sou um especialista no tema da metodologia jurídica.

Essa palestra será apresentada em seis partes. Elas são: Qual é o Direito que o Mercosul tem; Características do Direito da União Europeia; Metodologia jurídica europeia; Características do Direito da Integração; Sistema de Solução de Controvérsias no Mercosul; e Construção de uma metodologia jurídica mercosulista. Ao seu término, seguirão as considerações finais a cerca do meu pensamento.

\section{QUAL É O DIREITO QUE O MERCOSUL TEM}

Já há muitos séculos a Europa transfere a outros continentes conhecimentos e experiências, em um constante processo de circulação de modelos. No âmbito do Direito, mais recentemente, tais modelos vêm sendo observados com freqüência pelo continente americano, sempre que ocorre um desenvolvimento no processo de integração atualmente chamado de União Europeia.

Em 1957, foi criada a Comunidade Econômica Europeia, um bloco econômico que previu, naquele momento, como objetivo máximo, o alcance de um mercado comum, em um período de doze anos. Em função da criação de uma Comunidade, com vistas a um mercado comum, o Direito que surgiu para regulá-los foi chamado de Direito Comunitário. Com o tempo, ele assumiu características também supranacionais, e o bloco se expandiu qualitativa e quantitativamente.

Certo é que o desenvolvimento comunitário emprestou modelos jurídicos, e a atual União Europeia segue como exemplo para outras regiões do mundo que pretendem alcançar alguma forma de integração 
entre os seus países, e que, apesar de não seguirem um modelo idêntico, tomam alguns elementos substanciais para serem aplicados nos processos de integração desenvolvidos em seus territórios.

O primeiro desses modelos é a fase de mercado comum e a própria expressão mercado comum. O processo de integração que se desenvolve na região do mundo conhecida como Cone Sul, desde 1991, tem o nome de Mercosul devido à importação do objetivo e da expressão mercado comum do processo europeu (que aqui foram acrescidos da partícula do Sul: Mercado Comum do Sul). Com o Ato Único Europeu, de 1987, o termo mercado comum passou a ser afrontado por um novo termo, mercado interno. A entrada em vigor do Tratado de Lisboa, em 2009, aboliu, em definitivo, o termo mercado comum dos textos normativos.

Um segundo modelo interessante é o nome que foi dado para o ramo da Ciência Jurídica que regeria as Comunidades, Direito Comunitário (Europeu). Ocorre que, também por força do Tratado de Lisboa, duas remanescentes Comunidades Europeias foram incorporadas à União Europeia, que as substituiu à luz do Direito Internacional Público. Elas não mais existindo, o Direito Comunitário, em ambas facetas, intergovernamental e supranacional, passou a ser referido criativamente de Direito da União (Europeia).

Posto isto, cabe, então, discorrer sobre como nós, integrantes do Mercosul, compreendemos o novo Direito da União, e como entendemos que devem restar agora, depois dessas modificações terminológicas, as menções ao Mercado Comum do Sul, à fase de integração econômica pretendida por esse bloco, a de mercado comum, e ao Direito que rege esse processo.

Quase não prestamos atenção à distinção entre o Direito supranacional, privado, e o público, intergovernamental, da União. A distinção que mais nos interessa é aquela entre o Direito da Integração e o Direito Comunitário. Esse último deverá permanecer conhecido e utilizado entre nós, por força da sua popularização no meio acadêmico ou pelo fato de ainda ser almejado um mercado comum entre os Estados-partes do Mercosul. Contudo, em verdade, vemos diferenças entre esses ramos. Entre Direito da Integração e Direito da União há uma constante confusão. Temos que o atual Direito da União é aquele que diz respeito aos tratados constitutivos e ao direito do bloco europeu, não importando se de caráter intergovernamental ou supranacional. $\mathrm{O}$ Direito Comunitário é um Direito de Integração evoluído, aperfeiçoado, presente na União Europeia. Trata-se de uma disciplina autônoma que não está inserida no ramo do Direito Internacional Público.

Por outro lado, Direito da Integração é aquele que se refere aos processos ainda conduzidos unicamente pela intergovernabilidade, como é o caso do Mercosul. Embora afins em alguns aspectos, essas não são disciplinas idênticas, os termos não são sinônimos, versam 
sobre objetos diversos, tratam de conceitos próprios e abordam normas distintas, bem como usam metodologias jurídicas diferentes. Nos blocos econômicos em que a autonomia de seus integrantes é mais acentuada, e que, em contrapartida, a integração é menor, estar-se-á frente ao Direito de Integração, posto que fundados na intergovernabilidade. As normas desse último não possuem efeito direto, as comunitárias têm autonomia e estão hierarquicamente acima das nacionais.

A diferença essencial entre o ordenamento comunitário e o internacional consiste em que este não se impõe à ordem jurídica dos Estados, não existindo, como se sabe, uma ascendência jurídica do tribunal internacional sobre as cortes nacionais, até porque não existe um órgão institucionalizado com essa competência. Já em relação ao Direito da União ocorre, fruto de composição sui generis, uma subordinação das ordens jurídicas internas dos Estados-membros aos ditames do Tribunal de Justiça da União Europeia.

Nesse sentido, não há que se falar em Direito Comunitário do Mercosul, em Direito Comunitário da Integração, também não em Direito Comunitário Europeu, pois é somente o europeu que existe, e em Direito Europeu, também pelo fato de que a União Europeia não representa toda a Europa. Ela é a única organização, na atualidade, que tem Direito Comunitário ou da União. Assim sendo, não é necessário referir-se a ele como Direito Comunitário Europeu ou da União Europeu. O Mercosul é, em conclusão, regido pelo Direito da Integração.

A proposta, como sabido, é comparar a metodologia jurídica europeia com a metodologia do Mercosul, ainda em formação. Para tanto, o próximo tópico se dedicará às características do Direito da União.

\section{CARACTERÍSTICAS DO DIREITO DA UNIÃO EUROPEIA}

A doutrina classifica o direito europeu em sentido amplo e em sentido estrito ${ }^{3}$. O direito europeu em sentido amplo representa o direito de todas as organizações internacionais europeias e o direito europeu em sentido estrito abrange apenas o direito da União Europeia ${ }^{4}$. Esse é caracterizado hoje como Direito da União (Europeia) e se subdivide em direito primário e secundário da União Europeia.

A natureza desse direito implica que suas medidas terão efetiva precedência sobre as medidas nacionais. Além de tratados, o direito comunitário se manifesta através de regulamentos e diretivas, que são seus principais e preferenciais instrumentos para impor, no caso dos

3 KOENIG Christian, HARATSCH Andreas (2003) Europarecht. 4. ed. Tübingen: Mohr Siebeck, p. 1-2.

4 FASTENRATH Ulrich, MÜLLER-GERBES Maike (2000) Europarecht: Grundlagen und Schwerpunkte. Baden-Baden: Nomos Verlagsgesellschaft, p. 23. 
primeiros, ou sugerir, no caso das segundas, normas materiais, embora também tenha se valido de convenções e de outros instrumentos do direito internacional público clássico.

Antes da análise das fontes secundárias, principalmente $\mathrm{o}$ regulamento e a diretiva, que vêm na seqüência, vale abrir um espaço para afirmar que tão interessante quanto as classificações vistas é o papel do direito como elemento integracionista. $\mathrm{O}$ mais importante meio de integração é o direito.

O papel do direito na construção da União Europeia transcende uma, à primeira vista parcialmente negativa ótica, que vê tensões, conflitos, problemas em geral, problemas na transposição de regras e atinge o fato de ter exatamente servido para regular esta série de questões, ter dado caráter à União e ter sido a base científica para a definição de conceitos como o de mercado comum, mercado interno, concorrência e ajudas públicas, de empresa comunitária, bem como de tantos outros princípios, apenas para citar alguns exemplos. Em exaltação, lembra Lenz que "O direito comunitário é o que de mais precioso a Comunidade possui" 5 .

Demonstrada a relevância do direito para um processo de integração, retorna-se agora à apresentação das fontes secundárias. $\mathrm{O}$ direito secundário é produzido pelas instituições da União dotadas de poder legislativo, tal como o Conselho e a Comissão, e se apresenta primordialmente sob a forma de regulamentos e diretivas.

Os regulamentos são considerados os atos jurídicos mais importantes. Por intermédio desses diplomas legais as instituições podem interferir eficazmente nas ordens nacionais ${ }^{6}$. Assim, uma primeira diferença dos regulamentos para os demais diplomas é que eles possuem caráter geral, são obrigatórios em todos os seus elementos e diretamente aplicáveis, sem a necessidade de qualquer intervenção ou aprovação nacional, em todos os Estados-membros, e os outros obrigam somente destinatários certos e determinados. Isso significa que eles não precisam da colaboração dos órgãos legislativos nacionais, seja esta em forma de transformação, adoção, ratificação, incorporação ou recepção para gozarem de seus efeitos, ou de qualquer outro ato de transposição ou lei de execução ${ }^{7}$.

O segundo mais importante instrumento comunitário de direito secundário é a diretiva. Trata-se do mais interessante instrumento da

5 LENZ C. O. (1998) "Abschiedsrede". Europarecht, 33, p. 104.

6 STELZER Joana (2000) União Européia e supranacionalidade: desafio ou realidade? Curitiba: Juruá, p. 105.

7 Para STELZER, "Em decorrência desta especificidade, o regulamento é equiparado à lei nacional, estabelecendo obrigações ou conferindo direitos a (...) todos sob sua égide. A natureza jurídica do regulamento (...) representa verdadeira lei européia”. STELZER Joana (2000) União européia e supranacionalidade: desafio ou realidade? Curitiba: Juruá, p. 106. 
União $^{8}$. A diretiva é ato emitido pelo Conselho ou pela Comissão que vincula os Estados-membros quanto ao resultado a ser alcançado. Deixa, no entanto, às instâncias nacionais a competência quanto à forma e aos meios de implementação do seu conteúdo no ordenamento interno.

Como se observou, o regulamento busca uma uniformização jurídica. As diretivas, por sua vez, são mais flexíveis, e buscam apenas uma espécie de harmonização comunitária das várias legislações dos Estados-membros, promovendo uma aproximação legislativa. Não é, como os regulamentos, diretamente aplicável, necessitando, pois, de transposição. Esse mecanismo concede ao legislador nacional certo espaço de tempo quando da transformação em norma interna do assunto nela disposto.

Em síntese, os regulamentos são atos jurídicos primordiais, que prevalecem sobre todos os demais. Já as diretivas, também são obrigatórias, mas somente se aplicam aos Estados-membros aos quais sejam destinadas e deixam a eles margem de escolha quanto à forma e modo de implementarem os objetivos nelas determinados. Em algumas situações assumem aplicabilidade direta, especialmente se o conteúdo se apresentar de forma clara e incondicionada, quando favoreça um cidadão, haja expirado o prazo de transposição ou esta tenha se dado de maneira ilegal, assumindo, assim, por obra do Tribunal, natureza jurídica igual a dos regulamentos.

\section{METODOLOGIA JURÍDICA EUROPEIA}

As características que definem a supremacia nas relações existentes entre o direito comunitário e o direito interno estão contidas na própria jurisprudência comunitária. Esse tópico abordará os princípios retores que presidem a relação ${ }^{9}$, quais sejam os de efeito direto, primazia, segurança jurídica, aplicabilidade imediata ${ }^{10}$ e responsabilidade pela violação do direito comunitário ${ }^{11}$.

O princípio da segurança jurídica exige a eliminação do direito nacional incompatível com o direito comunitário. Ele "impõe aos Estados-membros uma integração do direito comunitário não só

8 BISCHOF Hans Helmut (1996) Europarecht für Anfänger. 2. ed. München: C. H. Beck'sche Verlagsbuchhandlung, p. 49.

9 CACHAPUZ DE MEDEIROS Antonio Paulo (1997) “Tribunais supranacionais e aplicação do direito comunitário: aspectos positivos e negativos”. In: VENTURA Deisy de Freitas Lima (org.) Direito Comunitário do MERCOSUL. Porto Alegre: Livraria do Advogado, p. 162-176.

10 Ver também sobre estes princípios OLIVAR JIMENEZ Martha Lucía (1997) "La comprensión de la noción de derecho comunitario para una verdadera integración en el Cono Sur". In: BASSO, Maristela (org.) Mercosul: seus efeitos jurídicos, econômicos e políticos nos estados-membros. 2. ed. Porto Alegre: Livraria do Advogado, p. 35-48.

11 Analisados também sob a esfera do Tratado de Assunção, cujos Estados-partes determinam a hierarquia das normas da integração, em SILVEIRA Paulo Antônio Caliendo Velloso da (1998) Defesa da concorrência no Mercosul: acordos entre empresas, abuso de posição dominante e concentrações. São Paulo: LTr, p. 102-115. 
de fato, mas também de direito, e que implica que não basta que os cidadãos possam invocar o direito comunitário no marco de litígios internos e que os juízes e tribunais estejam obrigados a rodear o direito comunitário de plena efetividade através dos princípios de primazia e eficácia direta, o que, em palavras do Tribunal, constituiria tão somente uma 'garantia mínima'. É necessário, ademais, que estes cidadãos estejam em situação de poder invocar o direito comunitário, situação que não ocorre, segundo o Tribunal, quando existe direito interno contraditório com o comunitário"12. Através de interação ${ }^{13}$, os Estados-membros exercem, verticalmente ${ }^{14}$, uma execução interna do direito gerado pelas instituições comunitárias, contribuindo para a eliminação das situações de incerteza jurídica provocadas pela existência de direitos incompatíveis.

Outro princípio é o da primazia. Equivale à determinação de valor prevalente ao ordenamento comunitário frente a qualquer norma contrária de direito interno e advém de adoção resultante da própria existência da União. Reflete e condiciona a lógica do sistema, bem como o seu funcionamento, e as relações do sistema jurídico comunitário frente aos sistemas jurídicos nacionais. A definição e as bases do reconhecimento da primazia do direito comunitário é trabalho jurisprudencial, já que não constou dos Tratados. Por tal é possível reiterar que a supremacia do direito comunitário na União Europeia foi buscada, construída de forma lenta, progressiva e jurisprudencial. A não-observância da primazia, princípio também amparado na reciprocidade do reconhecimento ${ }^{15}$, atenta contra a própria noção de processo de integração.

Pelo princípio da aplicabilidade imediata do direito comunitário se entende a incorporação do direito comunitário na ordem jurídica dos Estados-membros, tornando obrigatórias (vinculativas) para os cidadãos as disposições comunitárias. Portanto, determinar aplicabilidade à diretiva é lhe dar poder de modificar o direito interno, sem necessidade de transposição, ou qualquer outra intervenção dos ordenamentos jurídicos nacionais, e não lhe conferir aplicabilidade é fazê-la necessitar de complementos normativos por parte do legislador nacional.

A aplicabilidade, que tem sua origem na própria razão de ser do direito comunitário, não deve ser confundida com o efeito direto,

12 ALONSO GARCÍA Ricardo (1999) Derecho Comunitario y Derechos Nacionales: autonomía, integración e interacción. Buenos Aires: Abeledo-Perrot, p. 54.

13 O sentido do termo interação pode ser encontrado na obra de ALONSO GARCÍA, que tem como linha de raciocínio uma "permanente interação jurídica" entre os ordenamentos, onde encontra manifestação de uma certa homogeneização jurídica. Ibíd. p. 16, 17 e 53.

14 Exercício horizontal seria a participação dos Estados-membros na elaboração da própria normativa comunitária. Ibíd., p. 53.

15 CASELLA Paulo Borba(1994) Comunidade européia e seu ordenamento jurídico. São Paulo: LTr, p. 313. 
outro princípio de origem jurisprudencial. Por este princípio se permite ao particular reivindicar a realização do direito fundado na norma comunitária ou impedir a aplicação da regra nacional contrária à ordem comum.

Contudo, nem sempre se obtém a efetiva eficácia direta. A insuficiência na aplicação do princípio, em particular no caso das diretivas, é especialmente relacionada aos casos em que a norma comunitária deixa margem de apreciação na sua execução pelos Estados-membros. Então, alguns mecanismos auxiliam a compensar essa falta. São eles a eficácia interpretativa e a responsabilidade do Estado-membro por infração do direito comunitário, na verdade um princípio, que logo será analisado.

A consagração do princípio complementar ${ }^{16}$ da responsabilidade dos Estados-membros pelo incumprimento do direito comunitário se deu com o Caso Francovich ${ }^{17}$, de 1991, pelo qual os Estados-membros são obrigados a reparar os prejuízos causados aos particulares pelas violações do direito comunitário que lhes sejam imputáveis ${ }^{18}$. Com isso criou-se ao particular a possibilidade de buscar um direito à indenização. Assim, a não-observância da supremacia do direito comunitário gera conseqüências ao Estado-membro infrator.

A supremacia do direito comunitário na União Europeia é garantida pela jurisdição do Tribunal que, em seus acórdãos, vem estabelecendo princípios uniformizadores da interpretação do ordenamento jurídico comunitário, que é autônomo, produtor de diretos efeitos mesmo nos cidadãos. Em particular, viu-se que o efeito direto é reconhecer que uma norma prescreve em favor dos particulares uma série de direitos que podem ser buscados ante os tribunais, e primazia é a determinação da incorporação do direito comunitário ao direito interno, mas com valor prevalente. Ainda, que quando o juiz nacional não se abstiver de aplicar direito contrário ao ordenamento comunitário diretamente aplicável, pode o Estado ser responsabilizado a reparar os prejuízos aos particulares.

16 Segundo RODRÍGUEZ IGLESIAS, este princípio representa um complemento da proteção efetiva dos direitos dos particulares baseados no ordenamento comunitário. RODRÍGUEZ IGLESIAS Gil Carlos (1999) "Consideraciones sobre la formación de un derecho europeo". In: Anuario de Derecho Constitucional Latinoamericano. Buenos Aires: Konrad Adenauer, p. 28. Ainda, atualmente o processo sofre uma europeização e uma convergência cada vez maiores dos ordenamentos jurídicos nacionais. Ibíd. p. 27 e 48. Esta tendência só é limitada pelos princípios de competência de atribuição e de subsidiariedade, que fazem com que algumas parcelas de direito, como a penal, a de família e a de sucessões, ainda sejam regidas pelo direito interno.

17 Caso Francovich, EuGH, Slg. 1991, p. I-5357.

$18 \mathrm{O}$ assunto se apresenta de forma ampla e esclarecedora em RIBEIRO Marta Chantal da Cunha Machado (1996) Da responsabilidade do Estado pela violação do direito comunitário. Coimbra: Almedina, 213 p. Sobre a aplicação do princípio no Mercosul, ver BARRA Rodolfo (1997) "Responsabilidad del Estado por incumplimiento de las directivas comunitarias: el caso "Francovich" - una experiencia para el Mercosur". In: PÉREZ GONZÁLES Manuel et alli. Desafios del Mercosur. Buenos Aires: Ciudad Argentina, p. 413-453. 


\section{CARACTERÍSTICAS DO DIREITO DA INTEGRAÇÃO}

Ao contrário do que vimos que ocorre na União Europeia, a fragilidade institucional e jurídica ${ }^{19}$ do Mercosul é incontestável. As decisões dos órgãos chegam a vir paralelamente na forma de acordos de direito internacional público, como uma tentativa de garantir a eficácia ${ }^{20}$. Como observa Marques, sob nenhum dos três pressupostos, com os quais a visão jurídica da integração econômica avalia a firmeza e a seriedade de um processo (supranacionalidade, autonomia dos órgãos e criação de mecanismos de controle e garantia de segurança jurídica), poderia o Mercosul ser classificado como uma verdadeira integração ${ }^{21}$. Esses fatos estão muito agravados, devido aos longos anos que se passam desde que o Mercosul apresentou uma concreta evolução.

Essa estrutura frágil é ainda elemento de um dos paradoxos atuais do processo. Ocorre que, mesmo não tendo uma base jurídica sólida, o Mercosul já atua e mesmo legisla um modelo novo de direito ${ }^{22}$.

O processo econômico desenvolvido no Cone Sul vive, desde há muito, um momento de crise. Os Estados-partes que o integram não estão conseguindo colocar os propósitos do mercado comum acima dos interesses nacionais. Conseqüentemente, os temas que exigem decisões conjuntas, como o das liberdades econômicas fundamentais, estão paralisados. O prejuízo para a população desses países é imenso com essa Mercosklerosis (em alusão à Eurosklerose ${ }^{23}$ da década de 80 na Comunidade Europeia). O principal impacto desses problemas é observado na ausência do incremento da circulação de mercadorias, pessoas, serviços e capitais e na não implementação da legislação de proteção da concorrência.

Como exemplos de prejuízos, tem-se que a Argentina e o Brasil estão com problemas de relacionamento por conta de barreiras comerciais. Preocupados com as suas mazelas locais, esses importantes parceiros têm recorrido a constantes artifícios para salvaguardar os seus interesses. O Uruguai e a Argentina estiveram com a fronteira fechada por um longo tempo, devido a conflitos por razões ambientais. O Brasil e o Paraguai discutiram o valor da energia de Itaipu. O Uruguai não concordava que o Tribunal Permanente de Revisão do Mercosul fosse

19 Visões da fragilidade institucional podem ser vistas em MARQUES Claudia Lima (2001) "O 'Direito do Mercosul': Direito oriundo do Mercosul, entre Direito Internacional Clássico e Novos Caminhos de Integração". Revista da Faculdade de Direito da Universidade Federal do Paraná, 35, p. 83-87 e em VENTURA Deisy (2003) As assimetrias entre o Mercosul e a União Européia: os desafios de uma associação inter-regional. Barueri: Manole, 694 p.

20 OLIVAR JIMENEZ, Op. cit., p. 33-88.

21 MARQUES, Op. cit., p. 75-76.

22 DREYZIN DE KLOR Adriana (1997) El Mercosur: Generador de una nueva fuente de derecho internacional privado. Buenos Aires: Zavalía, 395 p. e MARQUES, Op. cit., p. 91-99.

23 DAUSES Manfred A. (2003) Rechtliche Grundlagen der Europäischen Wirtschafts-und Währungsunion. München: C. H. Beck, p. 65. 
em Assunção. As eleições diretas de representantes dos Estados-partes para o Parlamento do Mercosul estão em ritmo de espera. Esses entraves ilustram o momento que vive o Mercosul. A crise na economia mundial agravou os problemas, que já não eram restritos à questão financeira.

$\mathrm{O}$ resultado é que, a exatos vinte anos depois de sua criação, o Mercosul continua uma zona de livre comércio imperfeita e sequer conseguiu se consolidar como uma união aduaneira. O lamentável nesse quadro é o risco real de um retrocesso, de uma involução, nas relações de âmbito regional.

Mas, como visto, há uma parte da doutrina que tem por elogiável a experiência supranacional, embora acredite ser adequado o Mercosul restringir-se, no presente momento e estágio da integração, ao modelo intergovernamental. A esse modelo só coube um sistema de solução de controvérsias no Mercosul de caráter arbitral.

\section{SISTEMA DESOLUÇÃO DECONTROVÉRSIAS DO MERCOSUL}

Em função de obstáculos constitucionais e da opção pela intergovernabilidade, o mecanismo de solução de controvérsias assumiu uma característica diferente do existente na União Europeia. O primeiro documento que o regulou foi o Protocolo de Brasília, de 1991, de caráter transitório, que implantou um sistema arbitral.

As iniciativas tendentes a dar um impulso à integração pretenderam superar as deficiências derivadas da carência de um órgão que garantisse a interpretação uniforme do Tratado e tivesse capacidade para constatar e sancionar as violações às disposições emanadas dos órgãos do Mercosul, a adaptação do sistema ao estágio atual da integração e a necessidade de fortalecer a estrutura institucional. Para tanto, uma decisão de 18 de fevereiro de 2002 aprovou o Protocolo de Olivos, que derrogou o Protocolo de Brasília e a Decisão n. 17/98 CMC, o seu regulamento de aplicação, de dezembro de 1998. Ele entrou em vigor em 1o. de janeiro de 2004, juntamente com a Decisão n. 37/03 CMC, que é o seu regulamento de aplicação, derrogando o de Brasília.

Mesmo em meio aos períodos de crise, que desencadearam inúmeras medidas protecionistas e de represálias, o sistema de solução de controvérsias atingiu um relativo significado. As quatro primeiras controvérsias aceitas para ir ao tribunal arbitral ad hoc e que não resultaram em um acordo intermediário ${ }^{24}$ foram entre Brasil e Argentina. A primeira decisão do Tribunal Arbitral surgiu apenas em

24 Cerca de 450 consultas à Comissão de Comércio do Mercosul atingiram resultados satisfatórios e vieram a evitar o recurso ao procedimento arbitral. VENTURA, Op. cit., p. 240. 
abril de $1999^{25}$. O segundo laudo arbitral ${ }^{26}$ surgiu no mesmo ano, cinco meses após o primeiro. Já no começo de 2000 surgiu o terceiro laudo ${ }^{27}$. No ano de 2001 foram emitidos dois laudos arbitrais sobre conflitos em negociações comerciais ${ }^{28}$. Além desses, outros cinco se seguiram, computados apenas aqueles surgidos sob a vigência do Protocolo de Brasília. A análise desses laudos e daqueles que surgiram já sob a vigência do Protocolo de Olivos é a fonte de pesquisa principal para a tentativa de consagração de uma metodologia jurídica mercosulista.

A possibilidade de recurso ao Tribunal Permanente de Revisão do Mercosul, segundo o artigo 17 do novo documento, instalado solenemente em 13 de agosto de 2004 e que tem como sede Assunção, é o principal avanço em relação ao sistema estabelecido anteriormente ${ }^{29}$. Até então o sistema de solução de controvérsias não dispunha de instância recursal.

Outra inovação é a que consta do artigo 1o., n. 2, que faculta a submissão de controvérsias ao sistema de solução de controvérsias da OMC ou a outro sistema específico de comércio em que sejam partes individuais os Estados-partes do Mercosul. Este parágrafo também introduz uma vedação. Assim, uma vez iniciado um procedimento de solução de controvérsias de acordo com essa regra, nenhuma das partes poderá recorrer aos mecanismos estabelecidos nos outros foros, para a mesma questão. É o que se pode considerar a determinação da competência do órgão regional frente aos multilaterais por uma cláusula de eleição de foro.

Já o artigo 3o. se refere à novidade que possibilita ao Tribunal, mediante requisição dos Estados-partes, emitir opiniões consultivas sobre o direito da integração. A expectativa era que o instrumento servisse a uma interpretação uniforme das regras do Mercosul e a uma confiança na sua arquitetura judicial. Até os dias de hoje, surgiram três opiniões consultivas, nos anos de 2007, 2008 e 2009. Também elas constituem-se em importantes fontes de pesquisa principal para a tentativa de consagração de uma metodologia jurídica mercosulista.

Mais uma novidade a ser citada refere-se às fases do procedimento, já que as partes poderão passar das negociações diretas diretamente

$25 \mathrm{O}$ texto pode ser consultado em www.mercosul.org.uy/paginalesp.htm. A descrição e o desenvolvimento do processo podem ser vistos em SAMTLEBEN Jürgen (2000) "Erster Schiedsspruch im Mercosur: wirtschaftliche Krise als rechtliche Herausforderung?" Europäische Zeitschrift für Wirtschaftsrecht, 11(3), p. 77-80 e mais resumido em LEHMANN Julia (2001) "Neues von der Schiedsgerichtsbarkeit des Mercosur: ein Integrationsmotor à la Luxemburg?" Europäische Zeitschrift für Wirtschaftsrecht, 12(20), p. 623.

$26 \mathrm{O}$ texto pode ser consultado em www.mercosul.org.uy/paginalesp.htm.

$27 \mathrm{O}$ texto pode ser consultado em www.mercosul.org.uy/paginalesp.htm.

$28 \mathrm{O}$ texto pode ser consultado em www.mercosul.org.uy/paginalesp.htm.

29 PISCITELLO Daniel Pavón, SCHMIDT Jan Peter (2006) "Der EuGH als Vorbild: Erste Entscheidung des ständigen Mercosur-Gerichts". Europäische Zeitschrift für Wirtschaftsrecht, (10), p.301-304 e SCHMIDT Jan Peter (2005) "Neue Impulse durch institutionelle Reformen - der Mercosur ist wieder auf Kurs". Europäische Zeitschrift für Wirtschaftsrecht, (5), p. 139-142. 
para o procedimento arbitral, sem, necessariamente, percorrer a fase que envolve o Grupo Mercado Comum, como o Protocolo de Brasília apresentava. Assim, segundo artigo 6o., a intervenção do Grupo passou a ser opcional.

Uma última característica é que o Tribunal de Apelação pode ser acionado diretamente depois da primeira fase do procedimento, isto é, depois das negociações diretas, mediante acordo, segundo o artigo 23. Nessa hipótese, os laudos serão igualmente obrigatórios, mas sem a possibilidade de recurso. De fato, o Tribunal tem como objetivo julgar os recursos de revisão dos laudos dos tribunais ad hoc apresentados pelos Estados-partes e também atuar como única instância a critério das partes em conflito, ditar medidas cautelares e de urgência e responder a consultas dos Estados.

O sistema, mais ainda o do Protocolo de Brasília, chegou a receber manifestações favoráveis ${ }^{30}$. Críticas também não faltaram ${ }^{31}$. Dificilmente a doutrina o defende. Isso dá eco às manifestações de que o processo tem uma fragilidade institucional.

$\mathrm{Na}$ seqüência, esse artigo pretende, vistas essas observações preliminares, retratar os laudos surgidos sob o Protocolo de Brasília, apresentar e discutir as principais inovações advindas com o Protocolo de Olivos e, por fim, dar a conhecer os primeiros laudos surgidos sob a vigência desse novo documento para a solução de controvérsias no Mercosul.

\subsection{Laudos arbitrais surgidos sob o Protocolo de Brasília}

A primeira decisão do Tribunal Arbitral surgiu apenas em abril de $1999^{32}$. Com efeito, seis anos após a entrada em vigor do Protocolo de Brasília, durante os quais permaneceu como letra morta ${ }^{33}$, e do começo das críticas a ele dirigidas, bem como alguns meses após a sua regulamentação ${ }^{34}$, veio à tona o primeiro laudo arbitral, envolvendo uma questão que remontava ao ano de 1997. Ela versava sobre se regulamentações do controle de importação do Brasil infringiam o sistema de livre comércio do Mercosul. Brasil e Argentina estavam na disputa presidida por um uruguaio e com trabalhos realizados na sede do Mercosul, em Montevidéu. Segundo a posição argentina, as

30 WEHNER, Op. cit., p. 110.

Por JAYME foi apontada como um dos instrumentos para favorecer a integração em mercados como o Nafta e a Alca. JAYME Erik (1995) Identité culturelle et intégration: le droit internacional privé postmoderne. Recueil des Cours. The Hague: The Hague Academy of International Law, t. 251, p. 70.

31 PORRATA-DORIA JUNIOR Rafael A. (2004) "Mercosur: the commom market of the twentyfirst century?” Georgia Journal of International and Comparative Law, 32(1), p. 1-72., p. 24.

$32 \mathrm{O}$ texto pode ser consultado em www.mercosul.org.uy.

33 VENTURA, Op. cit., p. 228.

34 Decisão n. 17/98 CMC, de dezembro de 1998. 
medidas do Brasil representavam uma piora da situação até então existente, uma vez que a importação de determinados produtos passou a ter de cumprir específicos requisitos. Isso, juntamente com a cobrança de uma taxa, dificultava o acesso ao mercado brasileiro. $\mathrm{O}$ Brasil alegou que a eliminação de barreiras não-tarifárias era apenas um objetivo programático do Tratado em vista do futuro mercado comum. Segundo a decisão do Tribunal, o Brasil deveria eliminar o requisito das licenças não-automáticas para os produtos argentinos, uma vez que tal procedimento desrespeitava o Tratado ${ }^{35}$.

O que seria mesmo relevante de destacar do primeiro laudo, para a questão da metodologia jurídica, é o recurso que se fez ao direito comunitário, que foi expressivo. Esse é o direito, e não tanto aquele da OMC, em verdade, mais adaptado às situações jurídicas relativas à integração. Não se trata, evidentemente, de dizer que ele deveria ter sido aplicado ao caso em tela, mas de identificar na decisão o recurso de interpretação que foi usado, isso tudo considerando que inexiste fundamento jurídico que sustente a invocabilidade do direito da União no âmbito do Mercosul. Como se verá agora, na ausência de norma equivalente do bloco, como também ocorreu quando do emprego de normas da OMC, a tecnologia jurídica forjada na Europa, que para Ventura "constitui um dos mais fascinantes ramos do direito internacional moderno" ${ }^{36}$ poderia ser útil ao Mercosul. Foi o que o primeiro tribunal arbitral do Mercosul identificou, posto que proferiu uma decisão marcada por referências às definições e princípios do então direito comunitário.

$\mathrm{Eu}$ me refiro agora ao uso do esquema de averiguação das liberdades econômicas fundamentais do direito comunitário (Prüfungsschema der Grundfreiheiten). Esse esquema, que tem a sua base nos direitos fundamentais do direito alemão, é construído em cinco níveis, a saber os níveis de âmbito de aplicação/proteção das liberdades fundamentais (Schutzbereich), obstáculos, restrições e afetações às liberdades fundamentais (Beeinträchtigungen), justificativas à imposição de obstáculos, restrições e afetações às liberdades fundamentais (Eingriffsmöglichkeiten), limites das justificativas à imposição de obstáculos, restrições e afetações (Schranken-Schranken), e conseqüências jurídicas da imposição de obstáculos, restrições e afetações causados para as liberdades fundamentais (Rechtsfolgen bei Vertoß gegen die Grundfreiheiten).

Pareceu-me, que no tratamento da liberdade de circulação de mercadorias pelo primeiro laudo, a metodologia jurídica utilizada foi a europeia.

35 A descrição e o desenvolvimento do processo podem ser vistos em SAMTLEBEN, Op. cit., p. 77-80 e mais resumido em LEHMANN, Op. cit., p. 623.

36 VENTURA, Op. cit., p. 302. 
A liberdade de circulação de mercadorias tem como favorecidos os cidadãos de um processo de integração, os cidadãos de terceiros Estados que acompanhem as mercadorias, mesmo os não residentes. Obrigados a ela são os Estados-partes, a instituição comunitária e os operadores privados do mercado comum. A liberdade de circulação de mercadorias incide sobre mercadorias com valor econômico que tenham sido produzidas no âmbito territorial do processo de integração ou que estejam em livre prática. Os obstáculos, restrições e afetações que limitam a liberdade de circulação de mercadorias são as discriminações diretas, as discriminações indiretas, as barreiras não discriminatórias e as omissões estatais perante a obrigação de agir. Ademais, têm-se os direitos aduaneiros de importação e de exportação e os encargos de efeito equivalente, bem como as restrições quantitativas à importação e à exportação e as medidas de efeito equivalente. As justificativas à imposição de obstáculos, restrições e afetações à liberdade de circulação de mercadorias residem, entre as escritas, na moralidade pública, ordem pública e na segurança pública e naquelas indicadas no TFUE. Entre as não escritas, têm-se as exigências imperativas e os direitos fundamentais comunitários. Na União Europeia, os limites das justificativas à imposição de obstáculos proibidos pelo Tratado às liberdades econômicas fundamentais são determinados pelo princípio da proporcionalidade, princípio da propriedade; princípio da necessidade; pelo principio da adequação e pelos direitos fundamentais comunitários. As conseqüências jurídicas dos obstáculos, das restrições e das afetações às liberdades econômicas fundamentais variam conforme o ator seja a União Europeia e os seus órgãos, os Estados-membros da União Europeia ou os operadores privados do mercado comum.

$\mathrm{O}$ caso em tela versava sobre se regulamentações do controle de importação do Brasil infringiam o sistema de livre comércio do Mercosul. Segundo a posição argentina, as medidas do Brasil representavam uma piora da situação até então existente, uma vez que a importação de determinados produtos passou a ter de cumprir específicos requisitos. Isso, juntamente com a cobrança de uma taxa, dificultava o acesso ao mercado brasileiro. O Brasil alegou que a eliminação de barreiras não tarifárias era apenas um objetivo programático do Tratado em vista do futuro mercado comum. Segundo a decisão do Tribunal, o Brasil deveria eliminar o requisito das licenças não-automáticas para os produtos argentinos, uma vez que tal procedimento desrespeitava o Tratado $^{37}$. Da mesma forma, segundo o sexto laudo arbitral, o Tratado proibiria também as medidas que, ainda que não ajam diretamente de forma discriminatória, produzam o mesmo efeito, isto é, são faticamente

37 A descrição e o desenvolvimento do processo podem ser vistos em SAMTLEBEN, Op. cit., p. 77-80 e mais resumido em LEHMANN, Op. cit., p. 623. 
discriminatórias ${ }^{38}$.

Com isso tem-se que a liberdade de circulação de mercadorias também no Mercosul é realizada através da eliminação de direitos aduaneiros e de todos os demais diretos e indiretos obstáculos ao comércio intracomunitário, em especial as barreiras não tarifárias, as quantitativas e as medidas de efeito equivalente.

A verdade é que o caso representou uma esperança e um sinal de que questões envolvendo comércio pudessem vir a encontrar resultados satisfatórios, mesmo com o procedimento arbitral. Até uma primazia do direito do Mercosul em função desta decisão foi aviltada. Apesar de o laudo não se refirir expressamente a um tal princípio, isso decorreria do reconhecimento das normas do Mercosul por ele. A inexistência de normas de caráter supranacional não obsta a que a intervenção dos instrumentos internacionais se realize tendo em conta os fins, objetivos e princípios do sistema de integração, manifestou. Assim, estaria dizendo que os Estados não podem aplicar normas internas contrárias ao direito do Mercosul. E isso é o mesmo que dizer que as normas do Mercosul teriam primazia sobre o direito interno dos Estados-membros. Seria a construção e elaboração de um princípio, como fez o Tribunal de Justiça das Comunidades Europeias várias vezes. Lá na União o Tratado também não falava em uma primazia. Algumas outras possíveis interpretações de argumentações fundadas em direito internacional público e direito comunitário, encontradas no laudo, conduzem a pensar que ele construíra uma primazia do direito do Mercosul. Uma ausência de supranacionalidade e falta de efeito direto das normas não impediria atribuir primazia às suas normas. Embora o tema não seja garantido perante as Constituições, o laudo trouxe um sinal nesse sentido. Seguindo essa interpretação, a elaboração do princípio de primazia teria sido o eixo central do laudo, embora nunca mencionado, mas presente no seu conteúdo ${ }^{39}$.

Doce ilusão, pois em 1999 mesmo ambos os países se envolveram novamente no emprego recíproco de medidas não-tarifárias, o que deixava transparecer que a situação era de instabilidade incontrolável. De fato, esse caso e os futuros tinham mais a ver com a situação de crise do que com uma independência jurisdicional do sistema de solução de controvérsias ${ }^{40}$.

$\mathrm{O}$ segundo laudo arbitral ${ }^{41}$ surgiu no mesmo ano, cinco meses

38 FUDERS Felix (2008) Die Wirtschaftsverfassung des MERCOSUR: Eine rechtsvergleichende Darstellung unter besonderer Berücksichtigung des Rechts der Europäischen Union. Berlin: Duncker und Humblot, p. 223.

39 Pensamentos neste sentido podem ser vistos em DALLA VIA Alberto Ricardo (1999) "El primer laudo arbitral del Mercosur". Revista de Derecho del Mercosur, 4, p. 106 e 108. Em posição contrária, sobre a ausência de primazia do direito da integração, ver VENTURA, Op. cit., p. 133 e seguintes.

40 LEHMANN, Op. cit., p. 625.

$41 \mathrm{O}$ texto pode ser consultado em www.mercosul.org.uy. 
após o primeiro. A matéria envolvida versava sobre a existência de subsídios por parte do Brasil à produção e exportação de carne de porco. O Tribunal julgou improcedentes os argumentos levantados pela Argentina, exceto o de que o programa brasileiro de financiamento às exportações constituía um incentivo ${ }^{42}$. $\mathrm{O}$ ganho para o sistema de solução de controvérsias foi que o laudo analisou e tomou posição para cada ponto levantado. Outras conquistas foram de segurança jurídica, uma vez que o tribunal não aceitou posterior argumentação da Argentina sobre a situação atual dos fatos, que tinha se alterado desde a fase diplomática da solução, e, ao recusar um pedido também dela, deu importância para a necessidade de apresentação de provas do fato alegado e do dano sofrido pelos Estados-partes, o que não havia sido feito, mesmo que tal exigência não constasse expressamente do Protocolo de Brasília.

Já no começo de 2000 surgiu o terceiro laudo ${ }^{43}$. Desta vez foi o Brasil que acionou a Argentina, motivado por uma disputa sobre a legalidade de cláusulas de proteção envolvendo produtos têxteis. A crise que também atingiu o setor têxtil havia tornado a prática difícil de ser completamente eliminada da relação comercial entre os países. Desde o primeiro momento da tomada da Resolução 861/99 pela Argentina, o Brasil passou a agir contra, inclusive com medidas perante a Organização Mundial do Comércio (OMC). Uma solução só veio a ser tomada pelo tribunal arbitral que, ao observar que o direito do Mercosul não continha autorização que comportasse tais medidas, determinou que as salvaguardas impostas pela Argentina eram ilegais e deveriam ser suspensas. Importante é que já era possível vislumbrar um caráter de precedência entre o segundo e o terceiro laudo em relação ao primeiro ${ }^{44}$ e que, diferentemente do acontecido nos julgamentos anteriores, a decisão foi tomada levando em conta rigorosamente os argumentos apresentados pelas partes.

No ano de 2001 foram emitidos dois laudos arbitrais sobre conflitos em negociações comerciais ${ }^{45}$. Um, de 21 de maio, envolvia aplicação de medidas antidumping pela Argentina aos frangos provenientes do Brasil, cuja disputa remontava ao ano de 1997. Nela foi afirmado que a falta de uma regra específica sobre medidas antidumping no $\mathrm{Mercosul}^{46}$, apesar

42 Ver detalhes em LEHMANN, Op. cit., p. 623-624.

$43 \mathrm{O}$ texto pode ser consultado em $w w w$.mercosul.org.uy.

44 LEHMANN, Op. cit., Sobre a não garantia de que uma decisão arbitral pronunciada por um tribunal que não se repetirá possa constituir um precedente para as seguintes ver VENTURA Op. cit., p. 274 e seguintes. Sobre a não repetição dos juízes ver ARAUJO Nadia de (2004) O Tribunal Permanente de Revisão do Mercosul e as opiniões consultivas: análise dos laudos arbitrais, sua ligação com a common law e algumas idéias para o futuro, (no prelo), p. 12.

45 Os textos podem ser consultados em www.mercosul.org.uy.

46 FIGUEREDO Julio (2002) "Derecho de la competencia e integración económica: la situación en el Mercosur". CUADERNOS de EPOCA: Integración económica 2, p. 71-72. A específica questão do dumping, no laudo referido, foi analisada em BAARS Alf, BENKE Rafael Tiago 
da vasta atividade legislativa deste processo, e mesmo a não-ratificação do Protocolo de Defesa da Concorrência não significava que os Estados pudessem agir completamente de forma autônoma dentro do mercado. A decisão, no sentido de que as discutidas medidas antidumping eram compatíveis com o direito do Mercosul, motivo da improcedência do pedido do governo brasileiro, não parece ter sido satisfatória, pois observou-se que a porta permanecia aberta para o surgimento de novos laudos sobre a matéria ${ }^{47}$.

A outra decisão foi a primeira a não envolver os dois maiores países do bloco, mas sim o Uruguai e a Argentina. A questão referia-se a dúvidas sobre a autenticidade dos certificados de origem de bicicletas guarnecidas. A Argentina foi condenada a permitir o livre acesso ao mercado interno, como mercadorias intrazona, às bicicletas que tenham certificado de origem uruguaio ${ }^{48}$. É importante observar, ainda, que esta decisão mencionou preceitos do segundo laudo arbitral, anteriormente referido, tendo contribuído para a formação de uma jurisprudência no processo de integração ${ }^{49}$.

O sexto laudo do Tribunal Arbitral ad hoc do Mercosul solucionou a controvérsia apresentada pela República Oriental do Uruguai contra a República Federativa do Brasil sobre a "Proibição de Importação de Pneumáticos Recauchutados Procedentes do Uruguai”, em 9 de janeiro de 2002. O Uruguai manifestou que as restrições resultantes da portaria da Secretaria de Comércio Exterior (Secex) n. 8 de 25 de setembro de 2000, que dispôs pela não-concessão de licenças de importação de pneumáticos recauchutados e usados, prejudicavam principalmente a empresa Serisur, que vendia US\$ 1,2 milhão em pneus recauchutados ao Brasil. O desentendimento entre os dois países teve origem em uma portaria de 1991 do Departamento de Comércio Exterior brasileiro, que proibia a importação de produtos usados. Entretanto, a proibição aos pneus remoldados somente foi formalizada nove anos depois, com a portaria da Secex, que classificou como usados os pneus recauchutados. A defesa brasileira argumentou que a nova portaria pretendia corrigir falhas de nomenclatura nas operações de comércio exterior do país, o que, segundo o Itamaraty, permitia aos importadores burlar a legislação.

Juk (2001) "Antidumping no Mercosul: o Quarto Laudo Arbitral". Boletín Latinoamericano de Competencia. (13), p. 24-37.

47 BAARS Alf, BISCHOFF-EVERDING Peter (2002) "Antidumping und Ursprungsregime: das Schiedsverfahren im Mercosur wird zu einer festen Größe". Europäische Zeitschrift für Wirtschaftsrecht, 13(11), p. 332 e MARQUES, Op. cit., p. 99.

48 FONTOURA Jorge (2003) "A evolução do Sistema de Solução de Controvérsias: de Brasília a Olivos". Solução de controvérsias no Mercosul. Brasília: Câmara dos Deputados, p. 275. A descrição e o desenvolvimento do processo podem ser vistos em BAARS Alf, BISCHOFFEVERDING, Ibíd., p. 333-334.

49 Sobre a constituição, pouco a pouco e de forma integrada, de um conceito incipiente de direito comunitário do Mercosul e de um sistema de precedentes, o que se assemelha à tradição da common law, ver ARAUJO, Op.cit., p. 12-15. 
Para o governo Brasileiro os pneus recauchutados são bens usados, independentemente de ter sido objeto de processo industrial com efeito de prolongar sua vida útil. Com a referida portaria, o Brasil tentava reprimir todo tipo de importação de bens usados, proibidos desde 1991. O Uruguai também alegou que existiu um fluxo de comércio de pneus recauchutados entre os dois paises durante toda a década de noventa. Tal fluxo comercial provaria que o pneu recauchutado obteve a licença para a importação, não tendo sido, assim, tratado como um bem usado. A decisão manifestou que a Portaria n. 8 de 25 de setembro de 2000, da Secretaria de Comércio Exterior do Ministério de Desenvolvimento, Indústria e Comércio Exterior, era incompatível com a normativa MERCOSUL. O Brasil deveria, em conseqüência, adaptar sua legislação interna em consideração à citada incompatibilidade.

O sétimo laudo do Tribunal Arbitral ad hoc do Mercosul decidiu a cerca da controvérsia apresentada pela República Argentina contra a República Federativa do Brasil sobre "Obstáculos ao ingresso de produtos fito-sanitários argentinos no mercado brasileiro" ou, mais especificamente, barreiras da legislação ambiental brasileira para a entrada desses produtos no território nacional, em 19 de abril de 2002. O laudo deu ganho de causa à Argentina e impôs ao Brasil a incorporação das resoluções do Mercosul em seu ordenamento jurídico interno.

$\mathrm{O}$ oitavo laudo arbitral decidiu acerca da controvérsia entre a República do Paraguai e a República Oriental do Uruguai sobre "A aplicação do IMESI (Imposto Específico Interno) à comercialização de cigarros", em 21 de maio de 2002. O objeto da controvérsia era a incompatibilidade das normas uruguaias referentes à aplicação de um tal imposto. A forma de calcular a incidência de tal imposto seria discriminatória e contradiria os artigos $1^{\circ}$. e 7 do Tratado de Assunção e seu Anexo I. Em decisão, proferiu o Tribunal que o Uruguai deveria cessar os efeitos discriminatórios com relação aos cigarros paraguaios, baseados na condição de país não-fronteiriço, e assim também os demais efeitos discriminatórios que resultassem de medidas por via administrativa com relação aos cigarros de origem paraguaia.

\subsection{O surgimento do Protocolo de Olivos}

As iniciativas tendentes a dar um impulso à integração $0^{50}$ pretenderam superar as deficiências derivadas da carência de um órgão que garantisse a interpretação uniforme do Tratado e tivesse capacidade para constatar e sancionar as violações às disposições emanadas dos órgãos do Mercosul. Assim, uma decisão de 18 de fevereiro de 2002

50 SABIDO RODRÍGUEZ Mercedes (2003) "Un nuevo impulso a la integración jurídica en el Mercosur".In: CALVO CARAVACA Alfonso Luis, BLANCO-MORALES LIMONES Pilar. Globalización y Derecho. Madrid: Colex, p. 564-567. 
aprovou o Protocolo de Olivos $^{51}$ que derrogou o Protocolo de Brasília e a Decisão n. 17/98 CMC, o seu regulamento de aplicação, de dezembro de 1998. Ele entrou em vigor em 1o. de janeiro de 2004, juntamente com a Decisão n. 37/03 CMC, que é o seu regulamento de aplicação. A elaboração do referido documento foi impulsionada pela necessidade de adaptar o sistema de solução de controvérsia ao estágio atual da integração. Necessitava-se fortalecer a estrutura institucional.

A opção por um mecanismo arbitral foi mantida. Era pacífico o entendimento que a adoção, sem mais, em outros processos de integração, das características do Tribunal comunitário, não projetaria iguais resultados. As inovações introduzidas alcançaram a vários institutos. Da mesma forma, foram vários os temas que não apresentaram modificações. Entre as mais sensíveis inovações do Protocolo de Olivos e entre aqueles temas que não sofreram modificações, é necessário indicar: a possibilidade de recurso ao Tribunal Permanente de Revisão do Mercosul; possibilidade de submissão dos conflitos a outros foros; emissão de opiniões consultivas sobre o direito da integração; novo caráter optativo da intervenção do Grupo Mercado Comum; uso do Tribunal de apelação como única instância; e a manutenção do acesso indireto dos particulares. Ainda, cabe referir que o Protocolo estabelece as diretrizes que deverão ser observadas para a designação dos membros dos tribunais. Uma questão relevante é a disposição segundo a qual é recepcionada a faculdade que têm os Estados-partes de solicitar esclarecimentos sobre as pessoas que integram as listas apresentadas, já que essa possibilidade pode originar controvérsias. De fato, há um alto grau de subjetividade a rondar esse pedido de esclarecimento sem que esteja acompanhado de uma devida regulamentação no Protocolo, nem mesmo quanto ao prazo para que os pedidos sejam respondidos.

A sequência desse artigo trará algumas aplicações dessas novas regras a casos concretos, sendo que estes também servem à determinação de uma metodologia jurídica mercosulista.

\subsection{Laudos arbitrais surgidos sob o Protocolo de Olivos}

\section{O Tribunal Permanente de Revisão do Mercosul ${ }^{52}$ já foi convocado}

\footnotetext{
51 Para críticas e propostas ao Protocolo de Olivos ver MOYA DOMÍNGUEZ María Teresa (2003) "La Seguridad Jurídica en el Mercosur: el aporte del Protocolo de Olivos y la creación del Tribunal Permanente de Arbitraje". In: DROMI Roberto (dir.) Sistema Comunitário I. Buenos Aires: Ciudad Argentina, p. 308-347. A aprovação do Protocolo de Olivos se deu sem debate interno, que não o desenvolvido no plano diplomático. VENTURA Op. cit., p. 597. Mais sobre o tema ver em ARAUJO Op. cit., 28 p.; em FONTOURA Op. cit., p. 271-278 e em BARRAL Welber (2003) "O Protocolo de Olivos e as controvérsias no Mercosul". In: HOFMEISTER Wilhelm, TREIN Franklin. Anuário Brasil-Europa 2002: solução de controvérsias, arbitragem comercial e propriedade intelectual. Rio de Janeiro: Konrad Adenauer, p. 83-96, que também às páginas 94-96 trata das dúvidas remanescentes.

52 PISCITELLO, SCHMIDT Op. cit., p. 301-304 e SCHMIDT Op. cit., p. 139-142.
} 
em cinco situações, para laudos, e em outras três, para a emissão de opiniões consultivas, que serão vistas a seguir.

A primeira situação de exercício recursal resultou na deliberação do Laudo n. 1/2005 do Tribunal Permanente de Revisão constituído para conhecer o Recurso de Revisão apresentado pela República Oriental do Uruguai contra o laudo arbitral do Tribunal Ad Hoc da data de 25 de outubro de 2005, na controvérsia entre a mesma e a República Argentina sobre a "Proibição de Importação de Pneumáticos Remoldados procedentes do Uruguai", emitido na cidade de Assunção, em 20 de dezembro de $2005^{53}$. O objeto da controvérsia estava corretamente definido no item 90 do laudo em revisão, o primeiro surgido sob o Protocolo de Olivos, e tratava-se da Lei argentina n. 25.626, datada de 8 de agosto de 2002. O laudo em revisão foi considerado pelos árbitros do tribunal permanente possuidor de evidentes e graves erros jurídicos, o que o tornaria imperiosamente revogável. Assim, em decisão, o tribunal decidiu revogar o laudo arbitral em revisão, determinar que a Lei argentina n. 25.626 era incompatível com as normas do Mercosul e que a Argentina deveria derrogá-la ou modificá-la conforme o disposto na argumentação e fundamento da decisão. Por fim, decidiu o Tribunal que a decisão teria vigência até a data em que o Mercosul, pela via institucional apropriada, aprovasse uma norma sobre a questão debatida nos autos, relativa à importação de pneumáticos remoldados.

Em momento seguinte a essa decisão revisora, a Argentina interpôs um Recurso de Aclaração contra ela, o que fez com que o Tribunal Permanente tivesse que emitir o Laudo n. 1/2006, de caráter complementar ao Laudo n. 1/2005 ${ }^{54}$. Nele é observado que a Argentina apresentou uma solicitação de aclaração contendo trinta e um questionamentos bem diferentes e que um recurso como tal deveria ter por objeto a correção de um erro material, a aclaração de alguma expressão obscura ou a suplementação de alguma omissão em que o Tribunal tivesse incorrido e não renovar o debate sobre a interpretação e aplicação das leis, doutrina e jurisprudências feitas por um tribunal ao decidir um assunto. Tal medida da Argentina, de ter usado em grande parte o recurso de aclaração com a intenção de reabrir o debate sobre as questões decididas pelo laudo questionado, foi interpretada como uma tentativa de rediscutir o caso. Por tal, o laudo complementar terminou sendo muito mais extenso que o laudo arbitral objeto do recurso. Com isso, e por trata-se de um caso especial, já que era o primeiro recurso de aclaração que estava sendo julgado e o Tribunal não desejar que no futuro tal recurso fosse usado de maneira imprópria para reabrir debates, resolve ele não dar procedência ao recurso apresentado pela Argentina com relação ao laudo julgado em 20 de dezembro de 2005 sobre a

$\overline{53 \mathrm{O} \text { texto pode ser consultado em } w w w . m e r c o s u l . o r g . u y .}$

$54 \mathrm{O}$ texto pode ser consultado em www.mercosul.org.uy. 
proibição de importação de pneumáticos remoldados procedentes do Uruguai.

A terceira convocação do Tribunal Permanente de Revisão do Mercosul resultou no Laudo n. 2/2006 que julgou o Recurso de Revisão apresentado pela República Argentina contra uma decisão do Tribunal Arbitral Ad Hoc de 21 de junho de 2006, contida em uma Ata da Sessão n. 1, o que tornava o recurso peculiar, por se encarregar de definir a competência do mesmo para conhecer de recursos contra providências e decisões interlocutórias de tribunais ad hoc, que não o laudo definitivo ${ }^{55}$. O tribunal ad hoc havia sido constituído para julgar a controvérsia promovida pela República Oriental do Uruguai contra a República Argentina sobre a questão da "Omissão do Estado Argentino em Adotar Medidas Apropriadas para Prevenir e/ou Fazer Parar os Impedimentos à Livre Circulação pelas Barreiras em Território Argentino das Vias de Acesso às Pontes Internacionais General San Martín e General Artigas que unem as duas Repúblicas".

Em uma quarta sessão, em Assunção, no dia 08 de junho de 2007, emitiu o TPRM o Laudo n. 1/2007, a respeito de solicitação de pronunciamento sobre excesso na aplicação de medidas compensatórias, em uma controvérsia entre Uruguai e Árgentina sobre a proibição de importação de pneus remoldeados procedentes do Uruguai.

Por fim, também em Assunção, no dia 25 de abril de 2008, reuniuse o TPR pela última e quinta vez até os dias de hoje, para emitir o Laudo n. 1/2008, que tratou de uma divergência sobre o cumprimento do Laudo n. 1/2005 por parte da Argentina, alegada pelo Uruguai, com base no artigo 30 do Protocolo de Olivos. Em resposta, a Argentina alegou que o Tribunal considerasse uma reforma legislativa interna produzida como conseqüência direta do referido Laudo n. 1/2005, que lhe cabia cumprir. Mas o Tribunal entendeu que as medidas adotadas pela Argentina, o surgimento de uma lei interna, não supôs o cumprimento do Laudo n. 1/2005, e por tanto, a Argentina deveria derrogá-la ou modificá-la, bem como a lei anteriormente existente, para que a decisão tida com o Laudo n. 1/2005 tivesse o alcance necessário. Por fim, deu ao Uruguai a oportunidade de manter as medidas compensatória até quando se desse o cumprimento integral do Laudo.

\subsection{Observações finais sobre o sistema de solução de controvérsias}

O sistema do Protocolo de Brasília chegou a receber manifestações favoráveis, uma vez que teria evitado uma hipertrofia administrativa ${ }^{56}$, outrora já prejudicial a outros processos sul-americanos de integração,

$55 \mathrm{O}$ texto pode ser consultado em $w w w$. mercosul.org.uy.

56 BARRAL, Op. cit., p. 86. 
e consagrado instrumentos modernos de resolução de conflitos no direito das gentes ao utilizar-se de arbitragem comercial internacional ${ }^{57}$ e ao possibilitar aos particulares acorrerem a essas instâncias ${ }^{58}$.

Críticas também não faltaram. Na concepção de Porrata-Doria Júnior, o sistema então existente era extremamente fraco. Ele não era adequado para ser um mecanismo com o qual o Mercosul pudesse exigir o cumprimento das normas que ele emite. Para o autor, era necessário um sistema melhor ${ }^{59}$. Também não era esperado que o sistema gerasse um cabedal jurisprudencial mínimo necessário para a interpretação e aplicação das regras comunitárias. Para Martins, o sistema de tomada de decisões e de solução de litígios era frágil e obsoleto ${ }^{60}$.

É indiscutível que a grande maioria dos autores oferece críticas ao sistema de solução de controvérsias, quando não a tudo e às dessemelhanças que se apresentam com o processo comunitário, invariavelmente tido como maravilhoso, fascinante e fantástico.

Não apenas o sistema de solução de controvérsias, mas a ordem jurídica como um todo recebe considerações. A fragilidade institucional e jurídica ${ }^{61}$ do Mercosul é incontestável. Seguem existentes os mesmos problemas fundamentais: a provisoriedade de parte dos instrumentos vigentes, a ausência de uma instituição uniformizadora das decisões, que busque evitar soluções diferenciadas para situações aproximadas, e o não-estabelecimento de mecanismos pelos quais os particulares possam buscar, diretamente, a solução de seus problemas.

\section{CONSTRUÇÃO DE UMA METODOLOGIA JURÍDICA MERCOSULISTA}

Analisando certos documentos arbitrais do Mercosul, encontra-se o uso do método teleológico e do método comparativo.

\subsection{Primeiro laudo arbitral sob o Protocolo de Brasília e a expressão do método teleológico}

No ponto 7, que descreve as circunstâncias e os fatos, é objetada uma

57 Ver a aceitação desse instituto no esquema de integração do Nafta, por exemplo, em DREYZIN DE KLOR, Op. cit., p. 114-129.

58 SILVEIRA, P. A. C. V. da. Op. cit., p. 159 e BARRAL, W. Op. cit., p. 86.

59 PORRATA-DORIA JUNIOR Rafael A. (2004) "Mercosur: the commom market of the twenty-first century?" Georgia Journal of International and Comparative Law, 32(1), p. 24.

60 MARTINS Alexandre Marques da Silva (2000) "O Direito da Concorrência no MERCOSUL após o Protocolo de Fortaleza”. In: CASELLA Paulo Borba (coord.) MERCOSUL: integração regional e globalização. Rio de Janeiro: Renovar, p. 592-593.

61 Visões da fragilidade institucional podem ser vistas em MARQUES Cláudia Lima (1998) "Mercosul como legislador em matéria de direito do consumidor: Crítica ao Projeto de Protocolo de Defesa do Consumidor". Revista de Direito do Consumidor, (26), p. 56-58 e em VENTURA Op. cit., p. 108 e 589-601. 
norma brasileira que internalizou regras do Mercosul no ordenamento jurídico nacional, assim o Comunicado n. 37/97, que estabelece e consolida a lista de capítulos e produtos da Nomenclatura Comum do Mercosul sujeitos a licença não automática ou a licença automática com condições especiais. A alegação é que o Comunicado piora e agrava as condições de acesso ao mercado brasileiro de produtos argentinos, estabelecendo medidas administrativas equivalentes a restrições.

No ponto 16 e seguintes é alegado o descumprimento de normas do TA e de outras decisões do Mercosul, pois o TA expressaria, em seu artigo $1^{\circ}$., que o mercado comum implica, entre outras coisas, eliminar os direitos aduaneiros e as restrições não tarifárias e qualquer outra medida equivalente, bem como que o Anexo I do TA disciplina o que se entende por restrições.

No ponto 18, invoca a Argentina um compromisso de stand still em matéria de restrições não tarifárias e afirma que um novo sistema de importação implantado pelo Brasil reinstalava restrições anteriores, em condições mais gravosas, causando perda de segurança e certeza jurídicas, bem como fazia com que os exportadores argentinos devessem realizar trâmites adicionais de maior complexidade.

Já no ponto 19, a Argentina reitera que "uma interpretação funcional do TA deve levar em consideração o objeto e a finalidade do mesmo para interpretar o alcance dos compromissos que contém, assim como deve avaliar-se a obrigação de eliminar restrições segundo as Normas Complementares do próprio Tratado e do ACE 18". Isso tudo para dizer, no ponto 21 do laudo, que "A interpretação dos compromissos no Mercosul deve condizer com a finalidade do TA e de seus instrumentos complementares. Os Comunicados são contrários aos propósitos e finalidades do TA e afetam a reciprocidade. A exigência (...) viola o compromisso de eliminar as restrições não tarifárias", estabelecido nas normas do Mercosul. Bem, como se está trabalhando o primeiro laudo arbitral do Mercosul, pode-se dizer que a expressão "interpretação funcional do TA" é o primeiro indicativo dos rumos da metodologia jurídica mercosulista.

A partir do ponto 34 do laudo, está dito que o Brasil alegou que "O TA pode ser considerado um acordo quadro, instrumento internacional no qual traçam-se os objetivos e os mecanismos para alcançá-los, cujas disposições em geral programáticas não são, em sua maioria, juridicamente auto-aplicáveis", bem como que o mercado comum deveria ser alcançado gradualmente, e também que os Estadospartes procederam a diversas reavaliações dos prazos e dos objetivos do Mercosul, pelo que teriam abandonado a noção de eliminação de todas as restrições não tarifárias e passado a trabalhar a noção de harmonização de restrições não tarifárias, devido ao que não procederiam as reclamações da Argentina. Ademais, nessa linha de 
pensamento, o compromisso não seria de stand still, mas de tratamento nacional e de nação mais favorecida para as importações.

A partir do ponto 49 do laudo, afirmam os árbitros que "a solidez de ambas argumentações persuadiu o Tribunal da necessidade de desenvolver a fundamentação de sua decisão em uma linha de argumento incoincidente com qualquer das Partes, ainda que recolhendo contribuição das duas", e que "A profundidade e amplitude das fundamentações (...) indica claramente que a tarefa do Tribunal não consiste em decidir acerca da aplicação de alguma ou algumas disposições específicas e isoladas, mas em situar e resolver a controvérsia apresentada sob a perspectiva do conjunto normativo do Mercosul (...), interpretando-o à luz das relações recíprocas que emanam do conjunto dessas normas e dos fins e objetivos que os Estados-partes assumiram". Também, informa o laudo que "a questão proposta perante este Tribunal (...) não pode ser abordada como uma mera aplicação mecânica de disposições reunidas em um código ou texto unificado. Implica necessariamente realizar um amplo trabalho interpretativo para identificar os direitos e obrigações emergentes de um conjunto normativo de formação sucessiva".

A partir daí, o laudo passa a citar bibliografia comunitária, de Panayotis Soldatos e de Antonio Remiro Brotons, a respeito do que é considerado um "continuum integratif", no qual os diversos elementos adquirem significado numa visão de conjunto, e onde também "um regime que resulta do conjunto de suas disposições, forma um todo do qual não poderiam dissociar-se as distintas cláusulas para serem consideradas separadamente". Para julgar a compatibilidade de um regime de licenças nacional com a normativa do Mercosul o Tribunal deveria "buscar e identificar as regras jurídicas aplicáveis, guiado pelos fins e objetivos da ordem normativa criada pelas Partes", examinando o ponto sob o critério geral de interpretação estabelecido.

Mais adiante, vê-se no laudo as expressões de enfoque teleológico, valorização teleológica das obrigações, método teleológico, em momento em que são citados os doutrinadores comunitários Fausto de Quadros e Lecourt, e "in dúbio pro communitate". Substancialmente, aponta o ponto 59 que o trabalho interpretativo, que entende-se teleológico, deve levar em conta os objetivos e os fins do conjunto normativo e os alcances expressos nele.

Nos pontos 61 a 64, aduz o laudo que "Como corolário da interpretação teleológica e, em relação com a mesma, a jurisprudência comunitária, assinala Quadros (...), aplica o conceito de efeito útil ou de eficácia mínima das normas, Brotons (...), efeito útil significa 'escolher entre as várias soluções possíveis segundo os termos do tratado em seu contexto, aquela que melhor serve à satisfação de seu objeto e fim"' e que "Os conceitos expostos aplicam-se sem violência ao TA". 
A linha de argumentação seguida pelo Tribunal reconhece o papel central da liberação comercial no cumprimento dos fins e objetivos do Mercosul, a natureza inseparável das vertentes tarifária e não tarifária e a obrigação de eliminar totalmente as restrições em ambas, bem como que os cinco Anexos do TA, congruentes com esta interpretação, contêm obrigações concretas e auto-exequíveis, e nenhuma norma expressa derrogou a obrigação de proceder ao desmantelamento não tarifário, subsistindo o sistema do TA e as obrigações nascidas com ele, apesar de haver sofrido modificações, especialmente decorrentes da expiração do prazo originalmente pactado para o alcance do mercado comum. Essa seria a conclusão com base em uma interpretação harmônica do sistema, congruente e não contraditória com os fins e objetivos declarados e acordados pelas partes.

Em conclusão, decidiu o Tribunal que a controvérsia situava-se no conjunto normativo do Mercosul, que contra ele devia ser invocada uma incompatibilidade de um ordenamento nacional, que os instrumentos do processo de integração devem ser interpretados em forma teleológica, tendo em conta os fins, objetivos e princípios do sistema de integração, mesmo na ausência de normas de caráter supranacional, bem como que o TA e seu sistema normativo contêm disposições que fixam objetivos e princípios que estabelecem obrigações concretas para os Estados, entre as quais se inclui o programa de liberação comercial que deve ser completado tanto em relação às medidas tarifárias quanto às não tarifárias.

A necessidade de ser interpretado o Tratado de Assunção e a normativa do Mercosul funcional ou teleologicamente, enquanto mecanismo de integração, para desestimar medidas nacionais que sejam contrárias ao objetivo final neles estabelecidos, foi uma constante encontrada nos laudos arbitrais, até o nono, que torna a esses métodos, como se lê no seu item 19. Esse laudo, por sinal, no item 26, apresenta um outro método, chamado lógico-sistemático, que prega o atendimento aos princípios do Mercosul de gradualismo, flexibilidade e equilíbrio, consagrados no preâmbulo do Tratado de Assunção, que deveriam presidir a progressiva concretização, através da normativa vinculadora emanada dos órgãos do Mercosul, dos enunciados programáticos e princípios gerais essencialmente encerrados no corpo do Tratado.

Outra questão é que a doutrina deu ao laudo nono uma importância, por assim dizer, jurisprudencial, uma vez que nele foram usadas bases contidas em decisões arbitrais anteriores do Mercosul, que os árbitros aplicaram para a formação de sua decisão, a exemplo do que se vê no item 62 . 


\subsection{Primeiro laudo arbitral de revisão sob o Protocolo de Olivos e a expressão do método comparativo}

No item 3 do laudo, que trata do alcance do recurso e do alcance jurisdicional do TPR em recursos de revisão, é expresso que o trabalho do TPR deve restringir-se à interpretação e à aplicação das normas do Mercosul, no caso em tela, do princípio do livre comércio. Já no item 4 do laudo, está citado o então TJCE, quando é dito, em analogia, que a função dele é de interpretar a norma jurídica desde o ponto de vista jurídico, vale dizer, buscar o significado para precisar o seu alcance, e que muitas vezes esse Tribunal e o da Comunidade Andina das Nações julgaram casos com base na tese de incumprimento continuado das disposições do Tratado por parte dos Estados-membros, para ao final dizer que o TPR incorpora como preceito jurisprudencial tal concepção com o alcance mencionado e com todas as suas conseqüências. Vê-se, desde já, com clarividência, a expressão do método comparativo, pela invocação de instituições comunitárias.

Mais evidente nesse laudo é a invocação de jurisprudência, de normas e do sistema de averiguação das liberdades econômicas fundamentais usados pela União Europeia. Nesse sentido, o item 9 do laudo dá início à aplicação do que nele ficou conhecido como critérios de rigor, mas que, para a análise desse escritor, nada mais é que a aplicação do sistema de averiguação comunitário à viabilidade das exceções ao livre comércio, no caso em tela, a viabilidade ou não da exceção do meio ambiente à luz da normativa mercosulista. A aplicação do conhecimento comunitário é especialmente evidente no item 10 , onde se lê que "Normativamente, não existe no Mercosul um corpo legal que estabeleça clara e concretamente os critérios de rigor a serem analisados para a invocação de tais exceções, as quais sempre devem ser interpretadas com critério restritivo. (...) na hoje União Europeia (...) foram os tribunais comunitários os que primeiro desenvolveram tal conceito jurisprudencialmente". No item 11 do laudo, são citadas exceções ao princípio do livre comércio, que correspondem àquelas avaliadas e consideradas pelo sistema de averiguação das liberdades fundamentais comunitário, efetivamente destinadas a proteger tais valores, que, naquilo que for possível, não incidam no comércio e que finalmente sejam proporcionais com o fim perseguido.

O item 14 do laudo dá início à invocação do critério da proporcionalidade, pela análise de se a medida em questão é efetivamente restritiva ao livre comércio, que é o primeiro passo em um exercício de detecção de incompatibilidade entre normas autônomas dos Estados-membros e comunitárias. Isso é feito citando brevemente uma jurisprudência do TJCE, tida do caso Comissão contra República 
da Áustria, julgado em 15 de novembro de $2005^{62}$, no qual se teve que uma norma interna austríaca se constituiu em uma medida de efeito equivalente a restrições quantitativas, incompatível com as obrigações do então direito comunitário.

No item 15, o laudo dá início à avaliação do caráter discriminatório da medida objetada, um outro elemento do sistema de averiguação comunitário, novamente com base na jurisprudência comunitária antes citada, mas dessa vez considerando as observações do advogado geral L. A. Geelhoed.

No item 16, o laudo dá início à avaliação do terceiro pressuposto, que é o da justificação ou não da medida, sempre baseando-se em citações do julgado comunitário mencionado e das manifestações do advogado geral Geelhoed quanto ao cabimento das medidas com o objetivo perseguido por elas, um outro elemento do sistema de averiguação comunitário.

No item 17, o laudo, por fim, trata do quarto e mais difícil critério estabelecido pelo regime comunitário, que é o da proporcionalidade, tomando que toda medida que obste o livre comércio deva ser sempre avaliada restritivamente, consolidando, assim, a aplicação do sistema de averiguação comunitário a um laudo do Mercosul, ainda que isso não tenha sido dito expressamente no laudo em algum ponto. Nesse mesmo item, o julgador mercosulista cita, para compreender-se claramente o conceito de proporcionalidade, um Guia para a Interpretação e Aplicação dos artigos 28 e 30 do Tratado CE, de janeiro de 2001, emitido pela Divisão Geral do Mercado Interior, que comenta os ensinamentos do caso Cassis de Dijon, sobre o princípio geral da proporcionalidade.

Em conclusão, o primeiro laudo arbitral de revisão sob o Protocolo de Olivos revogou o laudo do tribunal ad hoc, porque ele possuía evidentes e graves erros jurídicos, conforme expresso no item 25 do laudo revisor, determinando que uma lei interna argentina era incompatível com a normativa do Mercosul, com base em uma correta interpretação e aplicação jurídica de exceções ao livre comércio, analisadas conforme o esquema de averiguação comunitário e a tese do incumprimento continuado do Tratado, o que representou, para nós, a expressão também do método comparativo na construção da metodologia jurídica mercosulista.

\subsection{Primeira opinião consultiva, opção decorrente das inovações advindas com o Protocolo de Olivos, e a expressão do método sistemático}

Em 2007, surgiu a primeira opinião consultiva do TPR. Uma

62 Assunto C-320/03, TJCE, caso Comissão contra República da Áustria, julgado em 15 de novembro de 2005. 
juíza de primeira instância do cível e do comercial de primeiro grau da jurisdição de Assunção, Paraguai, via Corte Suprema de Justiça do Paraguai, em autos em que litigavam duas empresas privadas, a argentina Laboratorios Northia Sociedad Anónima e a paraguaia Norte Sociedad Anónima, endereçou uma questão ao TPR. Ela girava em torno da prevalência do Protocolo de Buenos Aires sobre Jurisdição Internacional em Matéria Contratual, uma norma integracionista, sobre uma lei nacional paraguaia, que determinava o devido respeito, por essa, à eleição de jurisdição contratualmente estabelecida entre as partes, em conformidade com o artigo $4^{\circ}$. de tal Protocolo, sustentando a primazia do tratado sobre a lei.

Com efeito, e segundo o item A, 1 do laudo, a questão abarcava exclusivamente questões atinentes à interpretação jurídica da normativa do Mercosul, e se vinculava com causa que estivesse tramitando no Poder Judiciário do Estado-parte solicitante, com o que restavam cumpridas as exigências do Protocolo de Olivos para a submissão de opinião consultiva. Ainda, segundo o item A, 3 a aceitação da questão considerava a sua transcendental importância para assentar os sólidos cimentos do conceito, natureza e objetivo das opiniões consultivas dentro do processo de integração, dado o contexto da consulta, e segundo o item B, 1 a função do tribunal nos casos em tela era interpretar a norma comunitária desde o ponto de vista jurídico, vale dizer, buscar o significado para precisar o seu alcance, ainda que uma opinião consultiva não seja obrigatória, nem vinculante para o juiz nacional consultante. No mesmo item, lembram os interpretadores que na União Europeia, um recurso semelhante é sempre vinculante.

No item C, 1 buscando resolver já a questão, o tribunal informa que "As três características básicas do direito comunitário são: i) a aplicação imediata, ii) o efeito direto, iii) a prevalência normativa sobre o direito interno", no momento em que cita o jurista espanhol Ricardo Alonso García e os seus comentários ao caso Costa/ENEL, do TJCE, de 1964, que determinou uma origem pretoriana aos preceitos acima, especialmente o terceiro. Para esse dissertante, pende novamente o TPR ao método comparativo. Evidentemente que o TPR tinha a oportunidade de uma criação também pretoriana para inseri-las dentro do regime jurídico e da metodologia jurídica mercosulistas.

Mais adiante, no item E, 4 que discutia a prevalência da norma de direito da integração sobre a ordem pública nacional e internacional, novamente a jurisprudência do TJCE é citada, em especial o caso Dieter Krombach, de 28 de março de 2000.

$\mathrm{Na}$ sequência, antes de estimar a interpretação do articulado do Protocolo de Buenos Aires, informa o tribunal que o mesmo foi aprovado e ratificado por todos os Estados-partes do Mercosul, e que por tal, estaria legitimado para angariar prevalência sobre a lei nacional 
de todos os Estados. E no mesmo item F, 3 informa que o Protocolo de Santa Maria, invocado no processo para ser aplicado, não o poderia ser, dado que ainda não se encontra em vigor. Essa conclusão é bastante simplória, mas muito representativa para a formação de uma metodologia jurídica mercosulista, especialmente porque reafirma que nem mesmo uma norma do Mercosul, em comparação com as normas do direito internacional público, não é dispensada do processo de ratificação pelos Estados-partes para que entre em vigor.

Então, no item E do voto do árbitro Nicolás Becerra, lê-se que "Os Protocolos de Direito internacional privado são convenções internacionais, mas convenções muito particulares porque estão contidas em decisões do Mercosul -que têm caráter obrigatório segundo o Protocolo de Ouro Preto- e terem sido adotadas no marco de um processo de integração. Esses dados são fundamentais para a hora de fixar a interpretação de suas normas. É verdade que se tem que seguir o processo de incorporação previsto em cada Estado -dado que ainda não existe uma instância supranacional legiferante da que pudessem derivar normas como estas destinadas a sua aplicação direta nos países membros-, mas uma vez em vigor essas convenções devem interpretarse e aplicar-se em função das finalidades do Mercosul" e objetivos que os Estados-partes assumiram explícita e implicitamente ao adotarem tais normas, assim segundo um método nesse laudo chamado de interpretação sistemática, global.

As noções vertidas no Direito da União ainda não resultam transferíveis ao Mercosul, posto que esse não é uma organização supranacional. Ele carece de organismos comunitários com poderes legislativos delegados, pelo que as normas que emanam de seus órgãos carecem de eficácia direta e devem ser incorporadas aos ordenamentos jurídicos de cada Estado conforme os respectivos mecanismos constitucionais vigentes. É isso o que o Protocolo de Ouro Preto diz no seu artigo 42.

Discutindo o mesmo assunto e assumindo tais concepções, o voto do árbitro Ricardo Oliveira García, no item C, b, 21 cita o grande internacionalista da Universidade de Heidelberg, Prof. Erik Jayme, por ocasião de um prólogo que ofertou a um livro organizado por Diego Fernández Arroyo sobre o Direito Internacional Privado nos Estados do Mercosul, em 2003, que ali nos explicou que na Europa, os instrumentos usados no começo para a criação de um Direito Internacional Privado comum consistiram justamente em convenções entre os Estadosmembros da União Europeia, das quais derivaram, particularmente desde o Tratado da União Europeia, em 1992, em regulamentos e diretivas.

Enfim, em conclusão, o TPR afirma que a cláusula atributiva de competência jurisdicional contida no contrato realizado entre as duas 
empresas confrontadas na lide era válida, posto que as normas do Mercosul internalizadas prevalecem sobre as normas do direito interno dos Estados-partes, sejam elas de direito interno propriamente dito ou de direito internacional público e privado, e assim o caso foi respondido pelo TPR muito mais pela elucidação do aparente conflito entre duas fontes normativas diversas aplicáveis, o Protocolo de Buenos Aires e uma lei nacional paraguaia, do que por uma real interpretação de uma norma do Mercosul.

\subsection{O caso Sancor, mas que não chegou a gerar uma opinião consultiva}

Todavia, a mais interessante parece ser uma questão que não chegou a gerar efetivamente uma opinião consultiva. Em outubro de 2009, pela primeira vez a Argentina formulou uma questão ao TPR. Foi a primeira vez, também, que uma questão partiu diretamente de um tribunal superior de um dos Estados-partes do processo de integração, sobre um assunto originado dentro do órgão judiciário superior. Tal acontecimento demonstra que o mecanismo possui funcionalidade e vitalidade.

A pergunta proposta pela Corte Suprema de Justiça da Nação da Argentina ao TPR era a seguinte: ¿El Tratado de Asunción impone a los Estados miembros del MERCOSUR la obligación de abstenerse de establecer derechos a la exportación de mercaderías originarias de uno de ellos y destinadas a otros Estados miembros?

A discussão diz respeito à compatibilidade ou não de direitos de exportação aplicados pela Argentina com base na Resolução 11/2002 do Ministério da Economia com os artigos $1^{\circ}$. e $5^{\circ}$. TA e com os artigos $1^{\circ}$. e $2^{\circ}$. do seu Anexo I sobre o Programa de Liberação Comercial.

A empresa Sancor Cooperativas Unidas Limitadas, que promove uma demanda contra o Fisco Nacional (Dirección General de Aduanas), defende que a aplicação dos mencionados direitos de exportação entre os Estados-partes do Mercosul resultaria inválida por ser contrária ao TA. O caso envolve a exportação, pela mesma, de leite em pó e água mineral para o Brasil e para o Paraguai nos anos de 2002 e 2003.

Pois bem, a proposta de uma pergunta nesses termos dá margens a várias reflexões iniciais. Em primeiro lugar, decididamente, como informa Alejandro D. Perotti, o dia da sua proposição é histórico para a consolidação do direito do Mercosul. Isso é assim porque cabe esperar que o TPR, ao responder a questão proposta, dê continuidade ao decidido na Corte Argentina e confirme os direitos e as obrigações que o TA impõe aos Estados-partes e aos particulares. Também cabe referir que o TPR estará no ponto de decidir não unicamente se uma norma argentina é compatível com o TA, mas, uma questão de maior 
relevância, que é saber se o Mercosul gera obrigações aos Estados-partes e benefícios aos particulares. Em segundo lugar, a doutrina mercosulista entende que a resposta do TPR decidirá o futuro do Mercosul e, mais, que dela depende o próprio futuro do órgão jurisdicional, que busca a consolidação da sua posição institucional. Em terceiro lugar, não é possível esquecer que a resposta afirmativa a uma questão como essa foi um dos elementos essenciais para a afirmação e para o êxito do processo de integração da UE. Há quem tenha dito que quando uma pergunta assim, de um tribunal superior, chegava ao Tribunal comunitário na década de 60, o que ocorria raramente, até garrafas de champanhes eram abertas em comemoração.

Em quarto lugar, cabe refletir que se a resposta for um sim, é de se pensar que os direitos de importação também efetivamente seriam proibidos entre os Estados-partes do Mercosul, já que são tão proibidos quanto os de exportação. O TA refere-se à eliminação dos direitos aduaneiros e das restrições não tarifárias à circulação de mercadorias, sejam eles de importação ou de exportação. Os de importação estão, inclusive, citados expressamente no seu Anexo I sobre o Programa de Liberação Comercial, situação que não se passa com os de exportação.

Por fim, em quinto lugar, nessa hipótese de extensão dos efeitos da resposta da opinião consultiva às questões que envolvam uma importação, é sugerida a seguinte constelação. Vamos supor que um particular, morador de uma região fronteiriça, aproveitando o câmbio favorável, em um sábado de tarde, segue para a Argentina, para realizar compras de mercado elota o porta-malas do seu carro com as mesmas. $\mathrm{Na}$ ocorrência do fenômeno transfronteiriço, a autoridade brasileira tributa as mercadorias que ultrapassam a quota individual de importação por via terrestre. A quota de importação somente pode ser exercida a cada trinta dias (artigo $7^{\circ}$. da Instrução Normativa da Secretaria da Receita Federal n. 117, de 6 de outubro de 1998). O particular paga o tributo para não se incomodar com a sua senhora em casa, por conta de sua opção de fazer as compras na Argentina, até mesmo porque, inclusive com o tributo, elas sairiam mais em conta. Posteriormente, ele decide agir contra a autoridade judicialmente, invocando a liberdade de circulação de mercadorias garantida pelo artigo $1^{\circ}$. TA, um documento de direito internacional público, internalizado e em plena vigência, com o intuito de reaver os valores pagos, a seu ver cobrados de forma incompatível com o TA. No seu entendimento, também, a expressão do TA a respeito da liberdade de circulação de mercadorias é clara, o documento está em vigor e não há nada mais a fazer, do ponto de vista legislativo, para que a liberdade de circulação de mercadorias seja implementada. Com a questão proposta na opinião consultiva, o tribunal argentino pretende obter uma luz para julgar um caso um tanto semelhante a esse.

Que resposta daria o judiciário brasileiro no processo ora 
imaginado? Vamos supor que alega o autor que, ainda que algumas normas do TA sejam consideradas programáticas, as aplicáveis no caso envolvendo a liberdade de circulação de mercadorias são específicas e operativas. Uma das prováveis respostas do judiciário brasileiro, com base na alegação da autoridade fiscal, seria a de que a imposição dos direitos de importação é compatível com a Constituição Federal, está fundada em leis infraconstitucionais e que nenhuma norma do direito internacional existe que seja capaz de obstaculizar a imposição dos mesmos. Ademais, vai dizer que o TA é programático, motivo pelo qual não poderia ser deduzida a existência de um compromisso direto e indubitável do Brasil e dos demais Estados-partes de abster-se de estabelecer direitos de tributação como os ali discutidos. Para além, o tribunal nacional poderia invocar o artigo $7^{\circ}$. TA, que prevê que em matéria de impostos, taxas e outros tributos internos, os produtos originários do território de um Estado-parte gozarão, nos outros Estados-partes, do mesmo tratamento que é aplicado ao produto nacional. Em todo o caso, o tribunal nacional vai lembrar que o Mercosul tem um caráter frágil de supranacionalidade, ou quase nenhuma, o que determina uma reserva de soberania aos Estados-partes, bem como que o exercício da tributação e o do controle aduaneiro é uma das mais evidentes expressões dessa soberania. $\mathrm{O}$ Mercosul seria visto de forma programática, judicialmente como um acordo de mera facilitação para o comércio, com o que a norma que garante a liberdade de circulação de mercadorias se vê restringida e não é aplicada conforme o ideal expresso no TA. Ocorre que pensando em uma construção acadêmica, pode-se dizer que o Mercosul já dispõe de preceitos suficientes para impedir uma tributação discriminatória e já há preceitos suficientes para impedir o controle discriminatório de comércio exterior (fitossanitário, cotas/limites, proteção do mercado interno, proteção do trabalho externo, fraudes e segurança da saúde). Por tal é que a doutrina estrangeira pergunta por que o juiz não aplica o TA (documento de direito internacional público, totalmente internalizado) diretamente, com a sua proibição de estabelecimento de barreiras e direitos aduaneiros? No caso específico da liberdade de circulação de mercadorias, não há mais nada que ela possa vir a gozar, do que o que o TA já diz. Quando o Tribunal comunitário aplicou diretamente o Tratado, as normas das liberdades fundamentais expressavam bem menos proibições aos Estados-membros que as do TA dirigem aos seus Estados-partes. Houvesse vontade clara dos Estados-partes de exercitar isso, já estaria acontecendo. Nesse panorama, não sobra muito espaço para o juiz, como detentor de uma parcela de poder do Estado, alçar à realidade o ideal pretendido pelo Mercosul quando está evidente que os Estados-partes, e é de se pensar que até mesmo a maioria da população, não desejam essa ação. Possivelmente a mesma situação na Argentina ou no Paraguai teria um outro desenrolar, devido ao caráter 
supralegal que o TA deteria, do ponto de vista constitucional, nesses Estados-partes e também a uma abertura a uma supranacionalidade que os ordenamentos jurídicos de tais Estados-partes teriam, conforme manifesta a doutrina mercosulista ${ }^{63}$.

\subsection{Conceitos preliminares sobre a vigência das normas no Mercosul}

O regime estabelecido no Mercosul para a entrada em vigência das normas oriundas da atividade dos seus órgãos, em oposição ao de aplicabilidade direta, responde ao conceito formulado pela doutrina e positivado no Protocolo de Ouro Preto (POP) de vigência simultânea.

$\mathrm{O}$ artigo 40 do POP estabelece o procedimento que deve ser seguido para que uma norma tenha vigência. Ele expressa que, uma vez aprovada a norma, os Estados deverão adotar as medidas necessárias para a sua incorporação no ordenamento jurídico nacional. Terminado tal trâmite, deverá ser comunicada a Secretaria Administrativa do Mercosul, que se encarregará de comunicar o fato a cada Estado-parte. Somente então após 30 dias dessa comunicação é que as normas entram em vigor, simultaneamente, nos Estados-partes.

A falta de aplicabilidade direta das normas do Mercosul se vê refletida também no artigo 42 do POP. Esse artigo, apesar de reconhecer o caráter obrigatório das mesmas, expressa que elas, quando seja necessário, deverão ser incorporadas aos ordenamentos jurídicos nacionais mediante os procedimentos previstos na legislação de cada Estado-parte.

Assim, o sistema de vigência simultânea representa que, não obstante a obrigatoriedade da normativa do Mercosul, desde o seu acabamento a partir do consenso dado pelos Estados-partes, a sua vigência é postergada até a incorporação dessa norma no direito interno de cada um dos Estados-partes ${ }^{64}$. Essa é a disciplina do terceiro laudo arbitral do Mercosul, que expressa que não sendo incorporada a norma por cada Estado-parte, ela não estará em vigor. Essa obrigação de incorporar seria uma conseqüência direta da inexistência de aplicabilidade direta para a normativa derivada do Mercosul.

Como é possível imaginar a partir do conhecimento da metodologia jurídica europeia, a implementação desse regime de vigência simultânea apresentou, ao longo dos tempos, inumeráveis inconvenientes. Não há prazo para que os Estados-partes internalizem as normas do Mercosul e com muita dificuldade é que se sabe qual é

63 Sobre esses assuntos ver PEROTTI Alejandro D. (2011) Boletín electrónico de notíciasy documentación sobre procesos de integración (24). [online] disponível em: <http://www.grupodeintegracion.com. ar/2012/04/boletin-n-24-septiembre-octubre-2011.html $>$.

64 OLIVAR JIMENEZ, Op. cit., p. 33-88. 
a legislação vigente no Mercosul, isto é, quando é que está convertida uma norma do Mercosul em uma norma aplicável a um caso concreto ${ }^{65}$.

Em conclusão, tem-se que o processo de integração do Mercosul é repleto de particularidades em relação ao processo comunitário. Uma delas é a inexistência de um direito correspondente ao Direito da União na ordem jurídica do Mercosul. Isso é devido, substancialmente, a uma carência de vontade e de poderes autônomos dos seus Estados-partes e também à natureza internacional das normas do Mercosul ${ }^{66}$.

\section{CONSIDERAÇÕES FINAIS SOBRE UMA METODOLOGIA JURÍDICA MERÇOSULISTA}

A construção de uma metodologia jurídica mercosulista deve, necessariamente, ser fundada em um balanço dos dez laudos arbitrais tomados sob a égide do Protocolo de Brasília para a Solução de Controvérsias no Mercosul, dos dois laudos surgidos sob a vigência do Protocolo de Olivos, dos cinco laudos emitidos em grau de recurso pelo Tribunal Permanente de Revisão do Mercosul, e das três respostas dadas a questionamentos que lhe chegaram, na forma de opiniões consultivas, o novo recurso de que dispõem os tribunais dos Estados-partes para receberem esclarecimentos quanto à interpretação das normas do Mercosul.

Em princípio, viu-se que o sistema arbitral formou diversos tribunais. Tal fato torna difícil, acompanhando a doutrina, qualificar de jurisprudência a sucessão de decisões surgidas, justamente porque elas emanam de tribunais diferentes. Como se pode ver a partir da análise dos documentos judiciais e legislativos, nada garante que uma decisão arbitral pronunciada por um tribunal ad hoc possa constituir um precedente para as sentenças seguintes.

Em todo o caso, pelo contrário, também é possível afirmar que as sentenças arbitrais do Mercosul demonstraram claramente um critério de interpretação e fizeram avançar a discussão sobre o direito aplicável às controvérsias. Por exemplo, os tribunais proibiram a adoção unilateral de novas barreiras não tarifárias e de medidas de salvaguarda no comércio intrazona.

Segundo a doutrina, os primeiros tribunais, na condição de pioneiros, tiveram a incumbência de definir o papel dos árbitros e do próprio sistema arbitral. Uma questão saliente foi a pluralidade de fontes do direito invocadas pelas partes para fundamentar as demandas, e outra foi a relação entre o direito do Mercosul e o Direito da OMC,

65 BERTONI Liliana (2006) Laudos arbitrales en el Mercosur. Buenos Aires: Ciudad Argentina, p. 249-257.

66 OLIVAR JIMENEZ, Op. cit., p. 66-88. 
sendo que essa suscitou maiores polêmicas ${ }^{67}$.

Em relação à pluralidade de fontes de direito, para Ventura, os árbitros consideraram que sua função não era decidir sobre a aplicação de certas regras específicas ou isoladas, mas de resolver a controvérsia, no primeiro laudo, relativa ao conjunto normativo do Mercosul. Eles se comprometeram a interpretar a questão "à luz das relações recíprocas que emanam do conjunto dessas normas e dos fins e objetivos que os Estados-partes assumiram explícita e implicitamente ao adotarem tais normas, confirmados por seus atos posteriores no contexto de um projeto integrador comum" 68 . Para além, "os fins e objetivos não são um adorno dos instrumentos de integração, mas um guia concreto para a interpretação e para a ação"69.

Ao avaliar, no primeiro laudo, que o essencial para solucionar a controvérsia não consistia em analisar cada medida nacional adotada pelo Brasil, mas em saber se o regime brasileiro questionado era compatível com o sistema normativo do Mercosul, promoveu o tribunal uma interpretação teleológica, que pautou a ação dos Estados-partes.

A segunda decisão arbitral do Mercosul confirmou o critério de interpretação teleológica escolhido pelo primeiro tribunal ad hoc, privilegiando a realização dos objetivos do Tratado de Assunção e a aplicação das regras que dele derivam ${ }^{70}$. Inclusive, o primeiro laudo foi citado nele, a partir de diligência do árbitro indicado pelo Brasil, a fim de configurar paulatinamente uma jurisprudência para o Mercosul, a partir dos laudos ${ }^{71}$.

Tal orientação interpretativa serviu como orientação para todas as decisões arbitrais seguintes. É o caso do quinto laudo arbitral, no qual os árbitros afirmaram que uma tal medida não estava de acordo com o espírito do Mercosul de favorecer e estimular as relações comerciais entre os parceiros ${ }^{72}$.

Já a respeito de outro tema, levando-se em consideração que o Direito do Mercosul não seria, posto que jovem, capaz de oferecer todas as respostas necessárias ao deslinde das controvérsias, seria natural que os tribunais tivessem recorrido ao direito internacional em geral. Essa era a disciplina, por sinal, permitida pelo artigo 19 do Protocolo de Brasília.

Com efeito, a primeira decisão apóia-se nos princípios do direito internacional público e do então direito comunitário, de quem, por sinal, toma emprestadas inúmeras referências, e a segunda decisão refere as regras do comércio internacional, por meio de repetidas alusões às

67 VENTURA, Op. cit., p. 271-295.

68 Item 49 do primeiro laudo arbitral.

69 Item 58 do primeiro laudo arbitral.

70 Item 55 do segundo laudo arbitral.

71 VENTURA, Op. cit., p. 277 e nota de rodapé número 195.

72 Item 3.2.4 do quinto laudo arbitral. 
normas da OMC. Ao contrário de no primeiro laudo, que examinava igualmente uma controvérsia relativa à liberalização comercial, que ignorou por completo o direito da $\mathrm{OMC}$, o segundo laudo não hexitou em adotar como fonte de direito o Acordo Sobre as Subvenções e as Medidas Compensatórias, concluído no âmbito da Organização, tendo relegado o Tratado de Assunção e uma decisão do Mercosul a uma posição secundária ${ }^{73}$.

O critério teleológico de interpretação das normas do Mercosul foi confirmado pelo terceiro laudo arbitral, que à semelhança do segundo, referiu-se explicitamente à primeira decisão $\operatorname{arbitral}^{74}$, sem no entanto imitar o seu raciocínio.

Em um tópico intitulado "Quadro para interpretação das normas do Mercosul”, vê-se que "o Tribunal, no âmbito de sua decisão, levará em conta os princípios estabelecidos pela Convenção de Viena sobre os Tratados, de 1969, que codifica os princípios do direito consuetudinário internacional"75, conforme era facultado pelo Protocolo de Brasília.

$\mathrm{Na}$ disputa, a Argentina afirmava que as regras do Mercosul não excluem as disposições multilaterais. Se um tema foi objeto de regulação entre os países do Mercosul com regras que aprofundem os compromissos da OMC, estas obrigam os sócios e prevalecem sobre as regras multilaterais. No entanto, se uma matéria não foi regulada no Mercosul, os Estados-partes têm o direito de aplicar os instrumentos previstos no ordenamento da $\mathrm{OMC}^{76}$. Com isso, o terceiro laudo aduziu, além de uma hierarquia entre as fontes de direito, o princípio segundo o qual só se pode recorrer a outras fontes na ausência de norma do Mercosul aplicável.

A questão da aplicação do direito da OMC no âmbito dos laudos também foi aprofundada pelo quarto laudo. De qualquer forma, é forçoso, segundo Ventura, constatar que um número significativo de normas da OMC foi objeto de referências e de até mesmo transposição completa no direito do Mercosul. Para a doutrinadora, essas decisões sucessivas consolidaram o critério teleológico de interpretação do direito do Mercosul e fizeram avançar a reflexão sobre o direito aplicável às controvérsias surgidas então durante a vigência do Protocolo de Brasília $^{77}$.

Modestamente, posso me permitir dizer que estudei em algumas oportunidades e com certa profundidade determinados aspectos, a saber, as liberdades econômicas fundamentais e a liberdade de concorrência, do processo de integração que se desenvolve aqui na Europa. Com as leituras que fiz para preparar essa palestra, observei que o tema da

73 Items 56 e 57 do segundo laudo arbitral.

74 Item III C do terceiro laudo arbitral.

75 Item III C do terceiro laudo arbitral.

76 Item I C $2 \mathrm{~h}$ do terceiro laudo arbitral.

77 VENTURA, Op. cit., p. 286. 
metodologia jurídica é muito discutido no espaço europeu. Tenho comigo que as discussões vistas na Europa sempre serviram como fonte de inspiração para o Mercosul, e isso não só para descrever o estado atual do processo, mas também para ver o que poderá acontecer no futuro. Nesse momento, tenho que admitir que ainda não há muito de metodologia jurídica mercosulista. Portanto, podemos tentar construir para o futuro uma metodologia mercosulista. A questão é: A metodologia da integração que já existe na Europa, da qual todo o mundo fala, pode ser transferida para o Mercosul?

A primeira questão que pode ser de interesse é o problema da invocação do direito do Mercosul por privados, perante um tribunal nacional de um Estado-parte do Mercosul. Assim, 1) podem privados invocar as normas do tratado em relação a um Estado-parte? Alguém já tentou? Se a resposta for sim, teve sucesso? Caso não, então perguntase, porque não? (O Caso Porto de Belém "apenas confirma o processo de incorporação dos tratados previsto pela Constituição Brasileira, a despeito de sua complexidade e de seu arcaísmo, excluindo qualquer possibilidade de reconhecer uma exceção em benefício do processo de integração" 78 e em nada alterou a posição hierárquica das normas desse processo que são recepcionadas pelo ordenamento interno.); 2) podem privados invocar o direito do Mercosul em relação a outros privados? (É o caso da primeira opinião consultiva, de número $1 / 2007$, em que uma empresa situada em um Estado-parte buscou a concordância do TPRM sobre a prevalência de um protocolo que se refere ao direito processual civil internacional do Mercosul, sobre uma lei nacional de um outro Estado-parte, qual seja, o Protocolo de Buenos Aires sobre Jurisdição Internacional em Matéria Contratual, tentando com isso que fosse respeitada a eleição de jurisdição contratualmente acertada, em conformidade com uma norma do referido protocolo.) Se Sim, em quais ramos do direito é encontrado este efeito entre privados?; e 3) há uma carta de direitos fundamentais do Mercosul?

Enfim, há inúmeras questões a serem ainda trabalhadas. Como um integrante da comunidade do Mercosul, nunca havia estudado antes uma metodologia de integração com profundidade. Posso não ter tido os olhos preparados durante as recentes leituras, pois demorava para ver as citações e as expressões de uma metodologia do Mercosul que os meus interlocutores europeus encontravam com relativa facilidade. Agora sei que a metodologia não diz respeito apenas à questão da aplicação de uma lei ou de um Tratado, mas também ao método jurídico com que isso é feito, à maneira como se chega a um determinado resultado, quais são os caminhos e quais são os argumentos. Assim, as "numerous references to ECJ jurisprudence" mostram que o TPRM colhe inspiração nos casos europeus. A jurisprudência do TJUE é um fator muito importante na

78 VENTURA, Op. cit., p. 167. 
integração. Por exemplo, o efeito imediato das diretivas foi uma ideia do então TJCE. Se o TPRM continuar inspirando-se no TJUE, uma metodologia mercosulista virá, em muito breve tempo, à tona. Pensando além: Talvez possa existir um dia não só uma "metodologia europeia" (Europäische Methodenlehre), mas uma metodologia integracionista, isto é, se ter métodos jurídicos que sejam específicos para processos de integração regionais.

\section{REFERÊNCIAS BIBLIOGRÁFICAS}

ALONSO GARCÍA Ricardo (1999) Derecho Comunitario y Derechos Nacionales: autonomía, integración e interacción. Buenos Aires: AbeledoPerrot, $301 \mathrm{p}$.

ARAUJO Nadia de (2004) O Tribunal Permanente de Revisão do Mercosul $e$ as opiniões consultivas: análise dos laudos arbitrais, sua ligação com a common law e algumas idéias para o futuro, (no prelo), $28 \mathrm{p}$.

BAARS Alf, BENKE Rafael Tiago Juk (2001) "Antidumping no Mercosul: o Quarto Laudo Arbitral”. Boletín Latinoamericano de Competencia. (13), p. 24-37.

BAARS Alf; BISCHOFF-EVERDING Peter (2002) "Antidumping und Ursprungsregime: das Schiedsverfahren im Mercosur wird zu einer festen Größe". Europäische Zeitschrift für Wirtschaftsrecht, 13(11), p. 329-335.

BARRA Rodolfo (1999) "Responsabilidad delEstado por incumplimiento de las directivas comunitarias: el caso "Francovich" - una experiencia para el Mercosur". In: PÉREZ GONZÁLES Manuel et alli. Desafios del Mercosur. Buenos Aires: Ciudad Argentina, p. 413-453.

BARRAL Welber (2002) "O Protocolo de Olivos e as controvérsias no Mercosul”. In: HOFMEISTER Wilhelm, TREIN Franklin. Anuário Brasil-Europa 2002: solução de controvérsias, arbitragem comercial e propriedade intelectual. Rio de Janeiro: Konrad Adenauer, p. 83-96.

BERTONI Liliana (2006) Laudos arbitrales en el Mercosur. Buenos Aires: Ciudad Argentina, 415 p.

BISCHOF Hans Helmut (1996) Europarecht für Anfänger. 2. ed. München: C. H. Beck'sche Verlagsbuchhandlung, 183 p.

CACHAPUZ DE MEDEIROS Antonio Paulo (1997) “Tribunais supranacionais e aplicação do direito comunitário: aspectos positivos e negativos". In: VENTURA Deisy de Freitas Lima (org.) Direito Comunitário do MERCOSUL. Porto Alegre: Livraria do Advogado, p. 162-176.

CASELLA Paulo Borba (1994) Comunidade européia e seu ordenamento jurídico. São Paulo: LTr, 648 p.

DALLA VIA Alberto Ricardo (1999) "El primer laudo arbitral del Mercosur”. Revista de Derecho del Mercosur, 3(4), p. 104-108.

DAUSES Manfred A. (2003) Rechtliche Grundlagen der Europäischen 
Wirtschafts-und Währungsunion. München: C. H. Beck, 278 p. DREYZIN DE KLOR Adriana (1997) El Mercosur: Generador de una nueva fuente de derecho internacional privado. Buenos Aires: Zavalía, $395 \mathrm{p}$.

FASTENRATH Ulrich, MÜLLER-GERBES Maike (2000) Europarecht: Grundlagen und Schwerpunkte. Baden-Baden: Nomos Verlagsgesellschaft, $264 \mathrm{p}$.

FIGUEREDO Julio (2002) "Derecho de la competencia e integración económica: la situación en el Mercosur". In: Cuadernos de Epoca: Integración económica 2, p. 33-101.

FONTOURA Jorge (2003) "A evolução do Sistema de Solução de Controvérsias: de Brasília a Olivos". In: BRASIL. CÂMARA DOS DEPUTADOS (edit.) Solução de controvérsias no Mercosul. Brasília: Câmara dos Deputados, p. 271-278.

FUDERS Felix (2008) Die Wirtschaftsverfassung des MERCOSUR: Eine rechtsvergleichende Darstellung unter besonderer Berücksichtigung des Rechts der Europäischen Union. Berlin: Duncker und Humblot, p. 223. JAYME Erik (1995) "Identité culturelle et intégration: le droit internacional privé postmoderne". Recueil des Cours. The Hague: The Hague Academy of International Law, t. 251, p. 9-268.

KOENIG Christian, HARATSCH Andreas (2003) Europarecht. 4. ed. Tübingen: Mohr Siebeck, 420 p.

LEHMANN Julia (2001) "Neues von der Schiedsgerichtsbarkeit des Mercosur: ein Integrationsmotor à la Luxemburg?” Europäische Zeitschrift für Wirtschaftsrecht, 12(20), p. 622-625.

LENZ C. O. (1998) "Abschiedsrede". Europarecht, 33, p. 103-105.

MARQUES Cláudia Lima (1998) "Mercosul como legislador em matéria de direito do consumidor: Crítica ao Projeto de Protocolo de Defesa do Consumidor". Revista de Direito do Consumidor, (26), p. 53-76.

MARQUES Claudia Lima (2001) "O "Direito do Mercosul": Direito oriundo do Mercosul, entre Direito Internacional Clássico e Novos Caminhos de Integração". Revista da Faculdade de Direito da Universidade Federal do Paraná, 35, p. 73-100.

MARTINS Alexandre Marques da Silva (2000) "O Direito da Concorrência no MERCOSUL após o Protocolo de Fortaleza". In: CASELLA Paulo Borba (coord.) MERCOSUL: integração regional e globalização. Rio de Janeiro: Renovar, p. 569-598.

MARTINS Renata Rocha de Mello (2002) Verfassungskonformität des MERCOSUR in Brasilien. Baden-Baden: Nomos Verlagsgesellschaft, $221 \mathrm{p}$. MOYA DOMÍNGUEZ María Teresa (2003) "La Seguridad Jurídica en el Mercosur: el aporte del Protocolo de Olivos y la creación del Tribunal Permanente de Arbitraje". In: DROMI Roberto (dir.) Sistema Comunitário I. Buenos Aires: Ciudad Argentina, p. 308-347.

OLIVAR JIMENEZ Martha Lucía (1997) “La comprensión de la noción 
de derecho comunitario para una verdadera integración en el Cono Sur". In: BASSO Maristela (org.) Mercosul: seus efeitos jurídicos, econômicos e políticos nos estados-membros. 2. ed. Porto Alegre: Livraria do Advogado, p. 33-88.

PEROTTI Alejandro D. (2011) Boletín electrónico de notícias y documentación sobre procesos de integración (24). [online] disponível em: <http://www. grupodeintegracion.com.ar/2012/04/boletin-n-24-septiembre-octubre-2011. html>.

PISCITELLO Daniel Pavón, SCHMIDT Jan Peter (2006) "Der EuGH als Vorbild: Erste Entscheidung des ständigen Mercosur-Gerichts". Europäische Zeitschrift für Wirtschaftsrecht, (10), p. 301-304.

PORRATA-DORIA JUNIOR Rafael A. (2004) "Mercosur: the commom market of the twenty-first century?" Georgia Journal of International and Comparative Law, 32(1), p. 1-72.

RIBEIRO Marta Chantal da Cunha Machado (1996) Da responsabilidade do Estado pela violação do direito comunitário. Coimbra: Almedina, $213 \mathrm{p}$. RODRÍGUEZ IGLESIAS Gil Carlos (1999) "Consideraciones sobre la formación de un derecho europeo". In: ANUARIO de Derecho Constitucional Latinoamericano. Buenos Aires: Konrad Adenauer, p. 27-50.

SABIDO RODRÍGUEZ Mercedes (2003) "Un nuevo impulso a la integración jurídica en el Mercosur”. In: CALVO CARAVACA Alfonso Luis, BLANCO-MORALES LIMONES Pilar (edits.) Globalización y Derecho. Madrid: Colex, p. 555- 567.

SAMTLEBEN Jürgen (2000) "Erster Schiedsspruch im Mercosur: wirtschaftliche Krise als rechtliche Herausforderung?" Europäische Zeitschrift für Wirtschaftsrecht, 11(3), p. 77-80.

SCHMIDT Jan Peter (2005) "Neue Impulse durch institutionelle Reformen - der Mercosur ist wieder auf Kurs". Europäische Zeitschrift für Wirtschaftsrecht, (5), p. 139-142.

SILVEIRA Paulo Antônio Caliendo Velloso da (1998) Defesa da concorrência no Mercosul: acordos entre empresas, abuso de posição dominante e concentrações. São Paulo: LTr, 317 p.

STELZER Joana (2000) União européia e supranacionalidade: desafio ou realidade? Curitiba: Juruá, 198 p.

VENTURA Deisy (2003) As assimetrias entre o Mercosul e a União Européia: os desafios de uma associação inter-regional. Barueri: Manole, $694 \mathrm{p}$.

WEHNERUlrich(1999)DerMercosur:RechtsfragenundFunktionsfähigkeit eines neuartigen Integrationsprojektes und die Erfolgsaussichten der interregionalen Kooperation mit der Europäischen Union. Baden-Baden: Nomos Verlagsgesellschaft, 253 p. 